\title{
Christian Gunadi*
}

\section{Examining the Impact of Legal Arizona Worker Act on Native Female Labor Supply in the United States}

\begin{abstract}
Low-skilled immigration has been argued to lower the price of services that are close substitutes for household production, reducing barriers for women to enter the labor market. Therefore, policies that reduce the number of low-skilled immigrants who work predominantly in low-skilled service occupations may have an unintended consequence of lowering women's participation in the labor market. This article examines the labor supply impact of the Legal Arizona Workers Act (LAWA), which led to a large decline in the low-skilled immigrant workforce of the state. The analysis shows no evidence that LAWA statistically significantly affected US-born women's labor supply in Arizona. This finding is partly explained by an increase in native workers in household service occupations due to LAWA, which offset the decline in immigrants in these occupations and caused the cost of household services to be relatively uninfluenced by the passage of LAWA.
\end{abstract}

$\begin{array}{ll}\text { Current version: } & \text { January 16,2020 } \\ \text { Keywords: } & \text { immigration; female labor supply; LAWA } \\ \text { JEL codes: } & \text { J21, J22, J61 } \\ \text { Corresponding author: } & \begin{array}{c}\text { Christian Gunadi } \\ \text { christian.gunadi@email.ucr.edu }\end{array}\end{array}$

Department of Economics, UC Riverside, Riverside, CA 92521, USA.

(c) The Author(s). 2020 Open Access This article is distributed under the terms of the Creative Commons Attribution 4.0 International License (http://creativecommons.org/licenses/by/4.0/), which permits unrestricted use, distribution, and reproduction in any medium, provided you give appropriate credit to the original author(s) and the source, provide a link to the Creative Commons license, and indicate if changes were made. @_- Cite as: Christian Gunadi. IZA Journal of Labor Policy (2020) 10:3. 


\section{Introduction}

Between 1970 and 2000, the participation rate of female labor force in the United States increased from $43.4 \%$ to $61 \%$ (Acemoglu et al., 2004). Despite this large increase, women are still spending much more time on household works compared to men (Cortes and Tessada, 2011). ${ }^{1}$ At the same time, a recent work underscores the role of low-skilled immigrants who work predominantly in low-skilled service occupations in lowering the price of services that are close substitutes for household production (Cortes, 2008). As such, the influx of low-skilled immigrants has been argued to increase native women's participation in the labor market (Cortes and Tessada, 2011; Barone and Mocetti, 2011).

In this article, I examined the impact of the Legal Arizona Workers Act (LAWA) of 2007, which require all employers in Arizona to verify if a worker is authorized to work in the United States through the federal E-Verify system, on the native female labor supply. The adoption of LAWA led to a decline in the low-skilled immigrant population of Arizona by $86,800-93,000$ or approximately $1.5 \%$ of the state's population in 2006 (Bohn et al., 2014). ${ }^{2}$ Considering that the decline in low-skilled immigrant population would inevitably lead to the shrinking of its workforce size, the passage of LAWA could have an unintended consequence of reducing women's participation in the labor market.

To examine the labor supply impact of LAWA, I used the synthetic control method (SCM) proposed by Abadie and Gardeazabal (2003) and further developed by Abadie et al. (2010) and Abadie et al. (2015). This method derives a weight that combines states to create a new synthetic Arizona that best resembles the pre-LAWA Arizona's characteristics and trends. The posttreatment values of synthetic Arizona then serve as the counterfactual outcomes for Arizona. The use of SCM in comparative case studies has a few advantages over the classic difference-in-differences methodology. For example, the method reduces the arbitrary nature of choosing a "proper" control state by the researcher that is not always well justified. Additionally, as demonstrated by Abadie et al. (2010) and Abadie et al. (2015), the pretreatment characteristics of the treated state can often be much more accurately approximated by a combination of untreated states than by any single one.

The analysis yields a few main results. First, the number of low-skilled immigrant workers in the labor force shrank substantially in Arizona due to the passage of LAWA. In the absence of LAWA, I estimated that the share of low-skilled immigrants in Arizona's workforce would be higher by approximately $1.1 \%$ points or $9 \%$ of its level in 2006 . Despite this large decline, I found no evidence that LAWA significantly affects the native women's labor force participation rate or average weekly work hours. This result holds even among highskilled US-born women who are most likely to be affected by LAWA because of higher opportunity costs of spending time for household works compared to low-skilled native women. Perhaps surprisingly, I found no evidence that the implementation of LAWA led to a statistically significant increase in the average time use for housework, gardening, and caring for children among US-born women in Arizona. Further analysis shows that this result is driven partly by an increase in native workers in household service occupations due to the implementation of LAWA, which offset the decline in immigrants in these occupations and caused the cost of household services to be relatively uninfluenced by the passage of LAWA. This increase in native workers in household service occupations is consistent with relative 
task redistribution argument in which low-skilled immigration nudges US workers toward occupations that require higher communication skill to reduce downward pressure on their wages (Peri and Sparber, 2009; Peri and Sparber, 2011). As LAWA shrinks the low-skilled immigrant workforce in Arizona, there is less incentive for natives to specialize in occupations that require higher communication skill. Similarly, a recent work by Lee et al. (2019) also found evidence of US natives' occupational downgrading following Mexican repatriations in the 1930s.

This paper contributes to the new emerging literature that examines the role of low-skilled immigration in influencing women's labor supply decisions. Traditionally, the literature has focused on how immigration has affected the wages of competing US workers and on whether similarly skilled native and foreign-born workers are perfectly substitutable in production (e.g., Friedberg and Hunt, 1995; Borjas, 2003; Ottaviano and Peri, 2012). However, the works of Cortes (2008) and Cortes and Tessada (2011) underscore the importance of low-skilled immigration in reducing the price of household services and altering the optimal time allocation between household and market work for women. The authors found that high-skilled native women in US cities with a higher concentration of low-skilled immigrants are more likely to purchase housekeeping services, reduce the time spent doing household works, and supply more labor into the market. Since then, similar evidence was found in Europe (Farrí et al., 2011; Barone and Mocetti, 2011; Peri et al., 2013) and Hong Kong (Cortes and Pan, 2013). My analyses from the natural policy experiment in Arizona suggest that policies that lead to a decline in the low-skilled immigrant workforce may not necessarily decrease native women's participation in the labor market. In the case of Arizona, an increase in native workers in household service occupations due to the implementation of LAWA leaves the aggregate supply of workers in the household service occupations unaffected, attenuating the effect of LAWA on the cost of purchasing household services. It is worth noting that the findings presented in this study may not necessarily contradict the works of Cortes (2008) and Cortes and Tessada (2011). Recent studies have argued that the labor market effects of an increase in low-skilled immigrants might not be symmetric as reducing it through immigration restriction policy (Clemens et al., 2018; Lee et al., 2019).

This paper also contributes to the literature that examines the impact of interior immigration enforcement policy, in particular, the universal E-Verify mandate. Indeed, as noted by Clemens et al. (2018), the evidence on the labor market effects of immigration restriction policies is still limited. Previous works have studied the impact of the universal E-Verify mandate on the likely unauthorized population in the state that adopts it (Bohn et al., 2014; Orrenius and Zavodny, 2016), crime rates (Chalfin and Deza, 2018), and educational choice of US-born individuals (Gunadi, 2018). A closely related study is the work by Bohn et al. (2015) who found evidence of diminished employment among legal low-skilled men due to LAWA. In this paper, I extended the analysis of Bohn et al. (2015) by examining whether LAWA affects the labor supply and the time use on household works among US-born women. Therefore, I viewed the results presented in this study as complementing the findings of Bohn et al. (2015).

This paper is constructed as follows. Section 2 describes the background of LAWA and conceptual framework. Section 3 discusses the empirical methodology and data used in the analyses. Section 4 documents the results. Section 5 concludes. 


\section{Background and conceptual framework}

The universal E-Verify program such as LAWA can be traced back to the Immigration Reform and Control Act (IRCA) of 1986, which requires new hires to present documents verifying their eligibility to work legally in the US and imposes sanctions on employers knowingly hiring unauthorized immigrants. These measures to curb unauthorized employment in IRCA, however, have been argued to be ineffective because there was no reliable, quick way to verify the authenticity of the documents used to prove identity and work authorization (Cooper and O’Neil, 2005). To address this shortcoming, the E-Verify system was rolled out to several states in 1997 under the name of Basic Pilot. Participating employers enter the new hire information from the employment eligibility form (Form I-9), and E-Verify system checks that information with Social Security Administration and Department of Homeland Security databases. If there is a discrepancy, the employer is notified of a tentative nonconfirmation, and the new worker has 8 federal working days to contest the discrepancy. While the discrepancy is being contested, the employer is not allowed to fire the new hire because of the discrepancy. However, the employer has to terminate the employment of the new hire if the discrepancy is not resolved after that period. For authorized workers, the inaccuracy rate of E-Verify is approximately $1 \%$, while for unauthorized workers, the error rate is approximately $54 \%$ (Westat, 2009).

The Legal Arizona Worker Act was signed into law in July 2007 and implemented on January 1, 2008. It is the first law of its kind that requires all businesses in a state to verify the employment authorization of new hires through the federal E-Verify system. The literature provides guidance on how LAWA may adversely affect the labor supply of U.S.-born women. Recent works by Cortes (2008) and Cortes and Tessada (2011) argue that low-skilled immigration lower opportunity cost of working by reducing the price of services that are close substitutes for household production. If LAWA leads to higher cost of household services, mainly because of the decline in low-skilled immigrants predominantly working in this sector, the labor supply of US-born women would be adversely affected as it increases the opportunity cost of working.

It is worth noting that LAWA might not necessarily increase the cost of household services. Recent works have documented that immigration nudges US workers toward occupations that require higher communication skill to reduce downward pressure on their wages (Peri and Sparber, 2009; Peri and Sparber, 2011). A more recent study in Europe found that native European workers are more likely to experience upward mobility in their occupation status in response to immigrants' influx (Cattaneo et al., 2015). It follows that immigration restriction policy such as LAWA might lead to downward mobility in US-born workers' occupation status, resulting in more US-born workers filling low-status occupations such as household services. If this is the case, the cost of purchasing household services would be relatively unaffected by the passage of LAWA. I examined if this is indeed the case in the following analyses.

\section{Empirical methodology and data}

To examine the impact of LAWA, I used the SCM pioneered by Abadie and Gardeazabal (2003) and further developed by Abadie et al. (2010) and Abadie et al. (2015). Formally, consider J+1 states indexed by $j=0,1, \ldots, J$. Let the value $j=0$ correspond to Arizona, while the rest of the 
states $(j=1, \ldots, J)$ are candidate contributors to the control group (i.e., the donor pool). Let $G_{0}$ be a $(k \times 1)$ vector whose elements are equal to the values of the pretreatment characteristics of Arizona that we want to match as closely as possible. Similarly, let $G_{1}$ be a $(k \times J)$ matrix collecting the values of the same variable in the donor pool.

The SCM identifies the vector of weights $W^{*}=\left(w_{1}, \ldots, w_{j}\right)$, that minimizes the difference between $G_{0}$ and $G_{1} W$ :

$$
W^{*}=\operatorname{argmin}\left(G_{0}-G_{1} W\right)^{\prime} V\left(G_{0}-G_{1} W\right) \quad \text { subject to } \sum_{j=1}^{J} w_{j}=1, w_{j} \geq 0
$$

where $V$ is a $(k \times k)$ diagonal, positive-definite matrix that assigns weights according to the relative importance of pretreatment characteristics in the objective function. ${ }^{3}$ For the pretreatment characteristics in which the difference is to be minimized, I used the following variables: the outcome variable itself from 2002 to 2006, the unemployment rate, the employment rate, foreign-born population share, the share of whites in the population, the share of college-educated population, average age in the state, and the employment share of major industries such as construction, agriculture, and manufacturing. Once the optimal weighting vector $W$ is identified, both the pre- and posttreatment values for synthetic Arizona can be computed by weighting each state appropriately. ${ }^{4}$ The posttreatment values of synthetic Arizona then serve as the counterfactual outcomes for Arizona.

After synthetic Arizona has been constructed, the procedure to estimate the impact of LAWA follows the usual difference-in-differences framework:

$$
\mathrm{DD}=\left(\text { Outcome }_{\text {post }}^{\mathrm{AZ}}-\text { Outcome }_{\mathrm{pre}}^{\mathrm{AZ}}\right)-\left(\text { Outcome }_{\text {post }}^{\text {synth }}-\text { Outcome }_{\text {pre }}^{\text {synth }}\right)
$$

where Outcome $\mathrm{Aost}_{\text {pat }}^{\mathrm{AZ}}$ is the average value of the outcome of interest for Arizona in the posttreatment period 2007 through 2015 and Outcome $\mathrm{Ar}_{\text {pr }}$ is the corresponding average for the pretreatment period 2000 through 2006. Similarly, Outcome $\mathrm{p}_{\text {ost }}^{\text {synth }}$ and Outcome $e_{\text {pre }}^{\text {synt }}$ are the corresponding averages for the synthetic Arizona. To prevent possible bias in the estimate of the impact of LAWA, I excluded six other states (i.e., Alabama, Georgia, Mississippi, North Carolina, South Carolina, and Utah) that implemented similar universal E-Verify programs after 2007 from the donor pool. For most of the analyses in this study, I used the 5\% 2000 Census and 2001-2015 American Community Survey, available fromIntegrated Public Use Microdata Series (IPUMS) (Ruggles et al., 2015). ${ }^{5}$ The summary statistics are reported in Table 1. In general, high-skilled individuals are more likely to participate in the labor market compared to low-skilled individuals. Married women are also less likely to participate in the labor market compared to single women, which is consistent with the finding of Farrí et al. (2011) who found that women with family responsibilities have lower labor force participation rate.

\section{Results}

\subsection{LAWA and low-skilled immigrant workforce}

Figure la shows the year-by-year difference in the size of the low-skilled immigrant workforce of age 18-64 years and those with at most completed high school after LAWA between Arizona and its synthetic control. In the absence of LAWA, the size of the low-skilled immigrant work- 
force in Arizona is projected to keep increasing after 2007, albeit at a slower pace compared to that in the pre-2007 period. In actual Arizona, however, the size of the low-skilled immigrant workforce declined sharply from approximately 350,000 workers in 2006 to less than 300,000 by 2010 . The difference-in-differences estimate shows that there would be approximately 48,885 additional low-skilled immigrant workers in Arizona in the absence of LAWA (Panel A of Table 1). In terms of its share of the labor force, the share of low-skilled immigrants in Arizona's workforce declines by $1.1 \%$ points relative to its synthetic control after the passage of LAWA (Figure 2a and Panel A of Table 2).

To find out if this decline occurred simply because of chance instead of LAWA implementation, I conducted a permutation test as suggested by Abadie et al. (2010) and Abadie et al. (2015). The idea was to simulate a distribution of deviations between each state in the donor

Table 1 Summary statistics

\begin{tabular}{lcc}
\hline & Arizona & Other states \\
\hline US-born labor force participation & & \\
Low-skilled female & 0.66 & 0.68 \\
High-skilled female & 0.80 & 0.82 \\
Married women & 0.72 & 0.75 \\
Single women & 0.80 & 0.80 \\
Male & 0.77 & 0.80 \\
High-skilled male & 0.90 & 0.92 \\
US-born labor hours (hours >0) & & \\
Low-skilled female & 37.41 & 36.74 \\
High-skilled female & 38.78 & 38.19 \\
Married women & 37.56 & 36.94 \\
Single women & 39.61 & 39.05 \\
Low-skilled male & 42.12 & 43.18 \\
High-skilled male & 44.37 & 44.89 \\
Household service sector & & \\
Hourly earnings & 7.99 & 8.60 \\
\% self-employed & 0.28 & 0.28 \\
\% female & 0.60 & 0.68 \\
\hline
\end{tabular}

Notes: Estimates based on Integrated Public Use Microdata Series (IPUMS) 5\% 2000 Census and 2001-2015 ACS. ACS, American Community Survey.

Figure 1 LAWA and size of low-skilled immigrant workforce

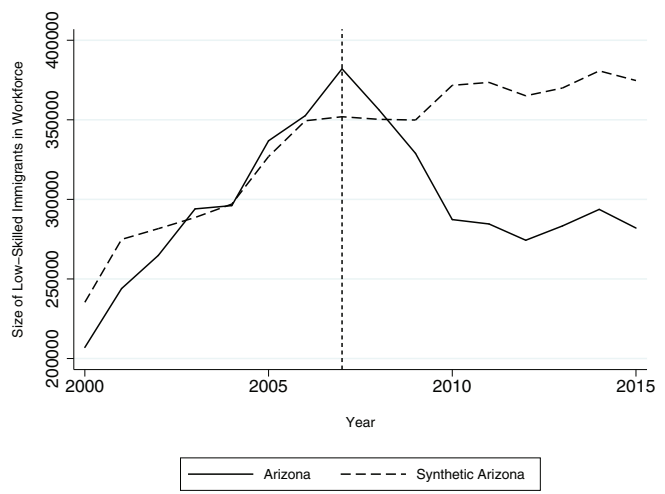

(a) Size of Low-skilled Immigrant Workforce

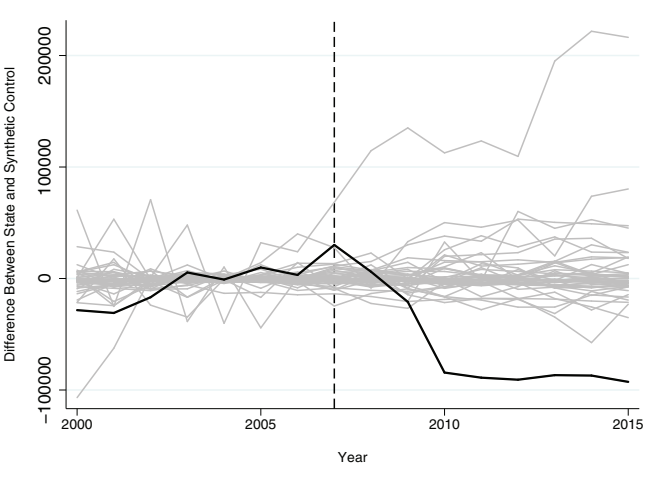

(b) Permutation Test 
pool and its synthetic control and examine whether Arizona shows a post-2007 deviation that is large relative to the whole distribution. That is, I applied the SCM used to examine the impact of LAWA in Arizona to every state included in the donor pool. ${ }^{6}$ If the deviation of post-2007 Arizona is not large relative to the empirical distribution of placebo effect estimates, it is quite likely that the difference between Arizona and its synthetic control after 2007 occurs simply by a chance. Figures $1 \mathrm{~b}$ and $2 \mathrm{~b}$ display the year-by-year difference between the outcome variable for each state in the donor pool and its synthetic control. ${ }^{7}$ The difference for each of the donor states is displayed with gray lines, while the difference for Arizona is displayed with a thick black line. The figures clearly show that the deviation in posttreatment Arizona is an outlier, implying the probability that the decline in the low-skilled immigrant workforce observed in Arizona relative to its synthetic control after 2007 occurred simply by a chance is unlikely. Indeed, the implied $P$-values (i.e., the probability that we observe a difference-in-differences estimate that is as large - negatively, in this case - as Arizona) of the impact of LAWA on both the size of the low-skilled immigrant workforce and its share in Arizona's workforce are 0.023 and 0.045 , respectively (Panel A of Table 2).

A concern is that the adoption of LAWA closely coincided with the Great Recession, and therefore, these findings may simply be driven by the economic downturn at the time. However, the SCM approach used already accounts for any changes that affect the country as a whole, and unless the Great Recession affects the Arizona labor market differently than the rest of the country, it will not threaten the validity of my findings. A concern is that one of the industries that were hit hardest by the Great Recession, construction, is a leading employer of low-skilled workers in Arizona. As noted above, however, I created synthetic Arizona that minimizes the difference in the employment share of the construction industry with actual Arizona, which should mitigate the possible bias arising from this concern. Furthermore, recent studies (Bohn et al., 2014; Bohn et al., 2015) show that the decline in the annual growth of employment in the construction industry in Arizona is similar to that in the neighboring states during the Great Recession, providing support to the credibility of the results presented in this study.

There is also a concern that another controversial Arizona state bill, SB 1070, which gave local law enforcement agencies more power in enforcing immigration laws and passed in 2010, may bias the impact of LAWA. However, before the law was supposed to take effect, a federal judge issued a preliminary injunction that blocked its most controversial provisions, and by 2012, the Supreme Court had struck down many of these provisions. It is unlikely, therefore,

Figure 2 LAWA and share of low-skilled immigrants in workforce

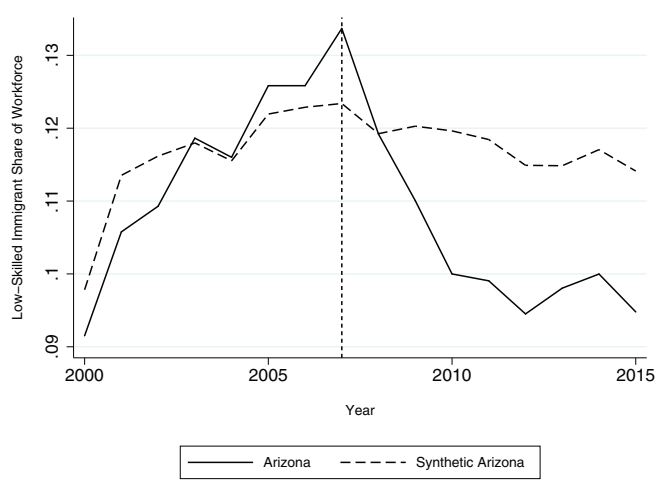

(a) Share of Low-skilled Immigrant in Workforce

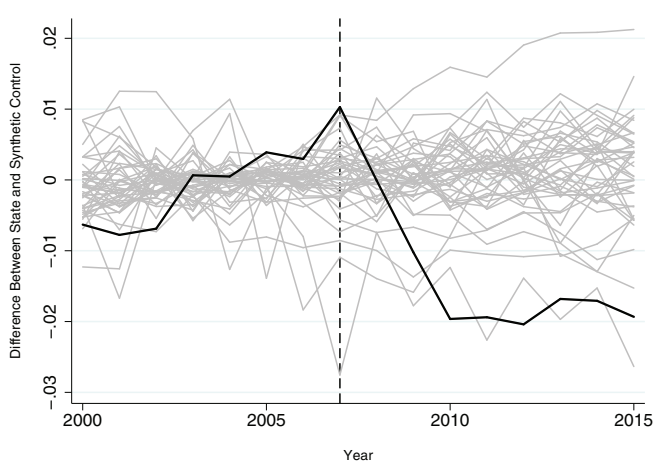

(b) Permutation Test 


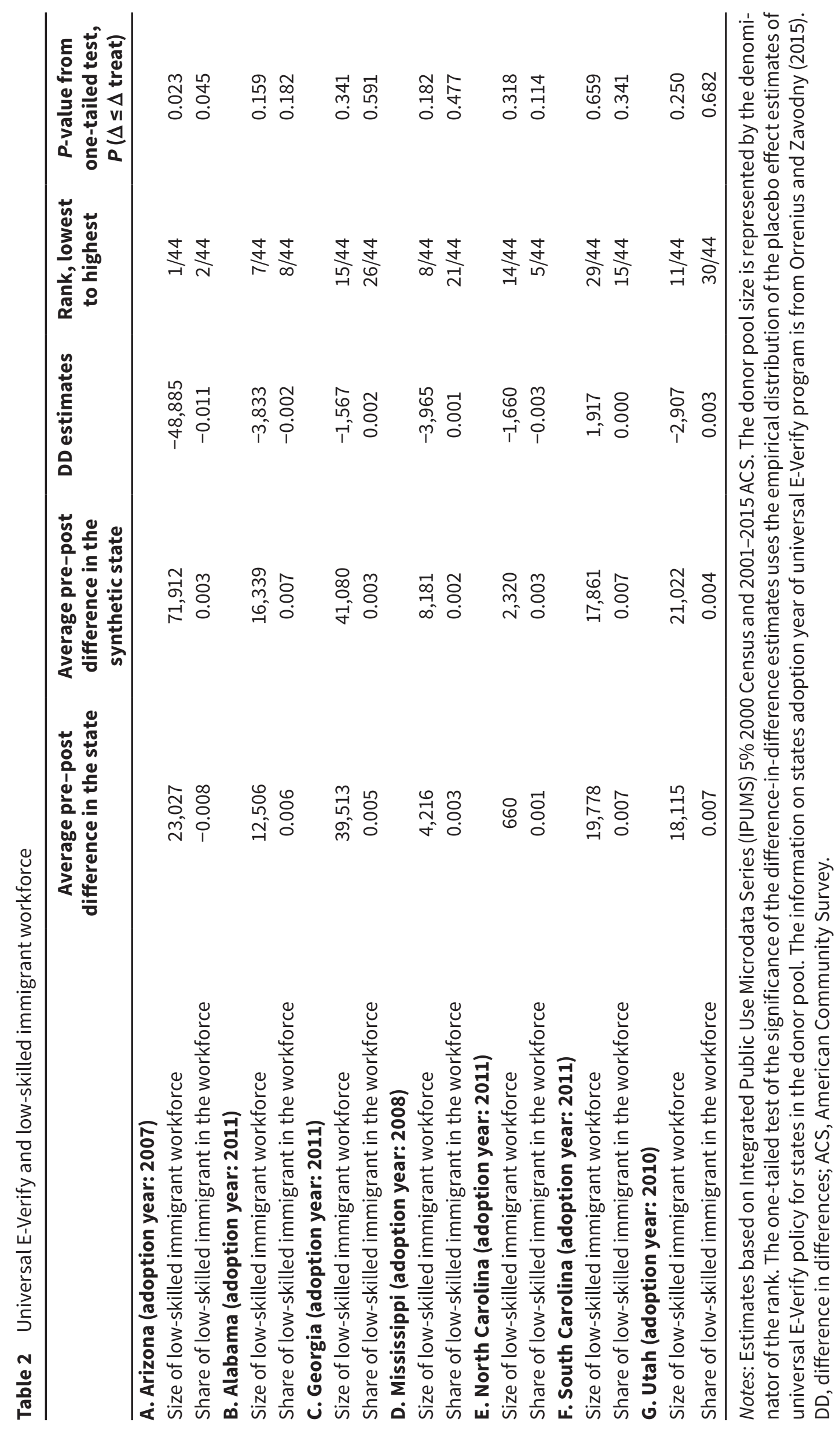


that Arizona state bill SB 1070 had much impact on reducing the low-skilled immigrant workforce in the state. Indeed, a recent study by Amuedo-Dorantes and Lozano (2015) found that the SB 1070 had a "minimal to null" impact on the share of noncitizen Hispanics in Arizona. ${ }^{8}$

Since LAWA was adopted in Arizona, six other states have implemented similar universal E-Verify programs. However, none of them have led to a decline in the low-skilled immigrant workforce as observed in Arizona (Panels B-G of Table 2 and Figures A1-A12). The answer to why we only observed a significant impact of universal E-Verify program in Arizona is outside the scope of this study. Nevertheless, there are a few possible reasons. For example, the scope of LAWA is broader because it requires all employers in Arizona to run new hires through the E-Verify system, while in some states such as Georgia, only businesses that use more than 10 full-time employees or hold a public contract are required to use the system. Similarly, the penalties for violation are considerably harsher in Arizona. A business license can be revoked permanently after the second violation in Arizona, while in other states such as North Carolina, failure to comply only results in monetary penalties of $\$ 10,000$ or more depending on how many times a business has violated the law. As only LAWA led to a statistically significant decline in the low-skilled immigrant workforce, I focused the rest of the analyses on the impact of LAWA.

\subsection{LAWA and U.S.-born female labor supply}

In the previous subsection, I have shown that LAWA has led to a significant decline in the low-skilled immigrant workforce in Arizona. Considering that low-skilled immigrants work disproportionately in the service sectors that are a close substitute for household production (Cortes and Tessada, 2011), LAWA may have an unintended consequence of reducing women participation in the labor market. To see if this is indeed the case, I examined the native female participation rate and average weekly usual hours in Arizona after LAWA was adopted using the SCM described earlier. In this analysis, I used a sample of US-born females in the prime working age (25-54 years old).

Figure 3 and Panel A of Table 3 show the impact of LAWA on the participation rate of highskilled native females with at least some college education. Because high-skilled women have higher opportunity costs for the time spent on household work compared to low-skilled women, the response to LAWA should be stronger among this group. Contrary to the expectation,

Figure 3 Native high-skilled female participation rate

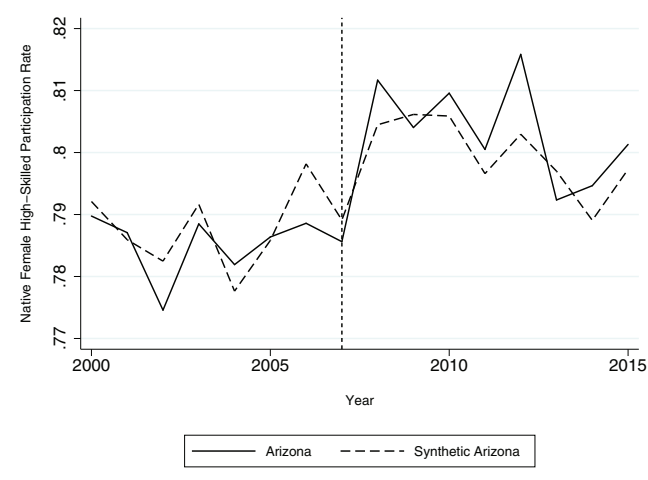

(a) Participation Rate

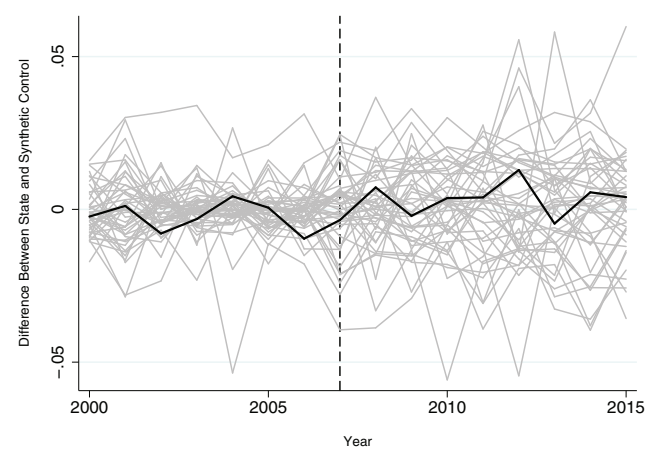

(b) Permutation Test 
Table 3 LAWA and native labor supply

\begin{tabular}{|c|c|c|c|c|c|}
\hline & $\begin{array}{l}\text { Average pre- } \\
\text { post difference } \\
\text { in Arizona }\end{array}$ & $\begin{array}{l}\text { Average pre-post } \\
\text { difference in } \\
\text { synthetic Arizona }\end{array}$ & $\begin{array}{c}\text { DD } \\
\text { estimates }\end{array}$ & $\begin{array}{l}\text { Rank, } \\
\text { lowest to } \\
\text { highest }\end{array}$ & $\begin{array}{c}P \text {-value from } \\
\text { one-tailed test, } \\
P(\Delta \leq \Delta A Z)\end{array}$ \\
\hline \multicolumn{6}{|c|}{ A. Native female participation rate } \\
\hline High skilled & 0.016 & 0.011 & 0.005 & $31 / 45$ & 0.689 \\
\hline Low skilled & -0.031 & -0.020 & -0.011 & $9 / 45$ & 0.200 \\
\hline Married & 0.017 & 0.009 & 0.008 & $36 / 45$ & 0.800 \\
\hline \multicolumn{6}{|c|}{ B. Native female hours per week } \\
\hline High skilled & -0.496 & -0.244 & -0.252 & $8 / 45$ & 0.178 \\
\hline Low skilled & -0.983 & -0.712 & -0.271 & $15 / 45$ & 0.333 \\
\hline Married & -0.148 & 0.070 & -0.217 & $13 / 45$ & 0.289 \\
\hline \multicolumn{6}{|c|}{$\begin{array}{l}\text { Wage per hour } \\
\text { percentile }\end{array}$} \\
\hline-100 & -0.317 & 0.106 & -0.423 & $7 / 45$ & 0.156 \\
\hline-75 & -0.319 & -0.170 & -0.149 & $16 / 45$ & 0.356 \\
\hline-50 & -0.505 & -0.395 & -0.110 & $15 / 45$ & 0.333 \\
\hline-25 & -1.168 & -1.017 & -0.151 & $18 / 45$ & 0.400 \\
\hline \multicolumn{6}{|c|}{ C. Native male participation rate } \\
\hline High skilled & -0.018 & -0.008 & -0.010 & $5 / 45$ & 0.111 \\
\hline Low skilled & -0.069 & -0.046 & -0.023 & $6 / 45$ & 0.133 \\
\hline \multicolumn{6}{|c|}{ D. Native male hours per week } \\
\hline High skilled & -1.314 & -1.083 & -0.230 & $14 / 45$ & 0.311 \\
\hline Low skilled & -2.157 & -1.377 & -0.779 & $5 / 45$ & 0.111 \\
\hline
\end{tabular}

Notes: Estimates based on IPUMS 5\% 2000 Census and 2001-2015 ACS. The donor pool size is represented by the denominator of the rank. The one-tailed test of the significance of the difference-in-difference estimates use the empirical distribution of the placebo effect estimates of LAWA for states in the donor pool. The pretreatment period is 2000-2006, while the posttreatment period is 2007-2015. Low-skilled female are defined as those with at most high school diploma. High-skilled female are defined as those with college education. LAWA, Legal Arizona Workers Act; DD, difference in differences; ACS, American Community Survey.

the difference-in-differences estimate shows that LAWA increases the participation rate of high-skilled native female in Arizona by $0.5 \%$ points, although this increase is not statistically significant with a $P$-value of 0.689 (Panel A of Table 2). I repeated this exercise by examining the impact of LAWA on the high-skilled female labor supply along the intensive margin (Figure 4). The high-skilled native female average weekly work hours in Arizona declined after the implementation of LAWA. However, this decline was also observed in synthetic Arizona, implying that even in the absence of LAWA, the average weekly hours of high-skilled native female would have declined anyway. Although the sign of the difference-in-differences estimate is negative, implying that high-skilled native women's weekly work hours decline by the passage of LAWA, this decline is not statistically significant with a $P$-value of 0.178 (Panel B of Table 3).

Figures 5 and 6 show the corresponding impact of LAWA on the low-skilled native female labor supply with at most high school education. The low-skilled native women's participation rate and average weekly hours declined after LAWA was enacted in 2007. Once again, however, this decline is also observed in synthetic Arizona, suggesting that low-skilled native women's participation rate and average weekly work hours would have declined anyway in the absence of LAWA. The difference-in-differences estimate shows that LAWA led to a reduction in native 
Figure 4 Native high-skilled female weekly hours (hours $>0$ )

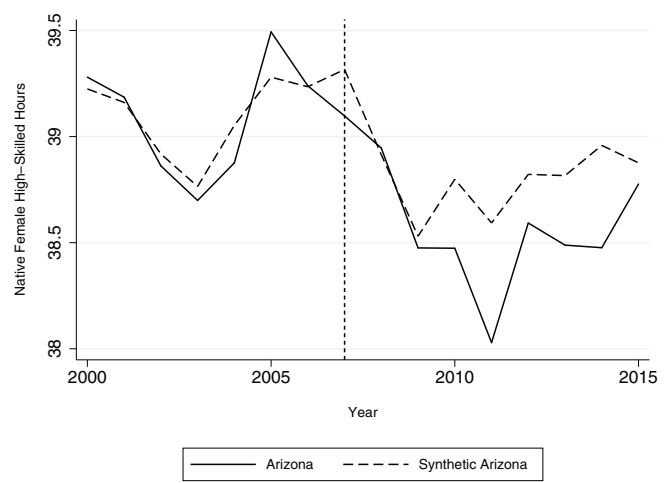

(a) Weekly Hours

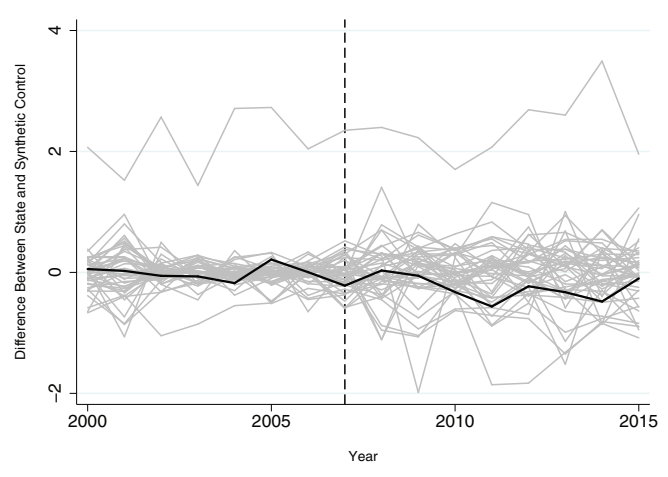

(b) Permutation Test

Figure 5 Native low-skilled female participation rate

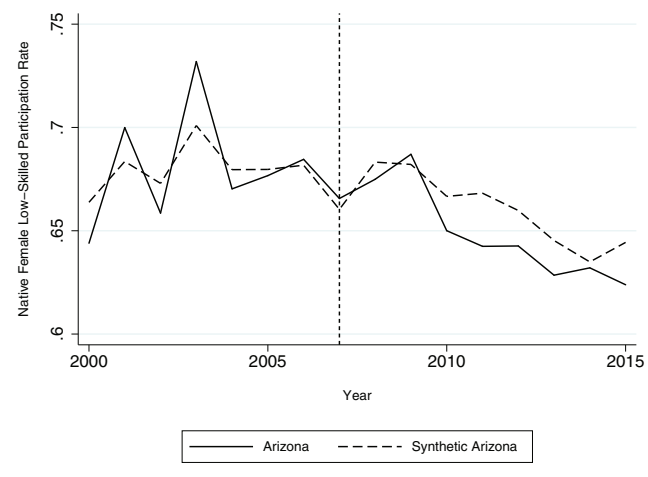

(a) Participation Rate

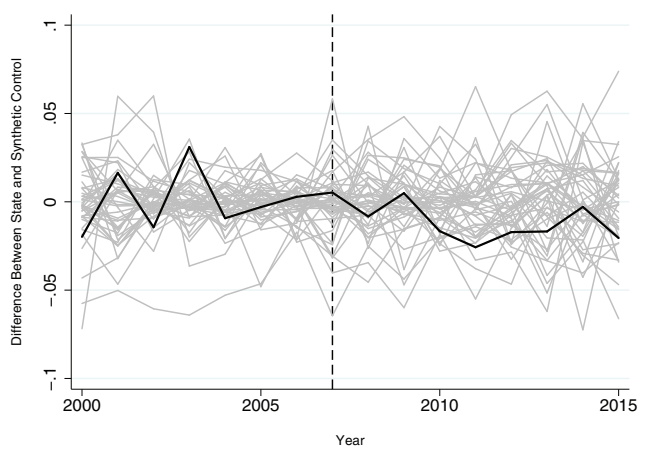

(b) Permutation Test

Figure 6 Native low-skilled female weekly hours (hours $>0$ )

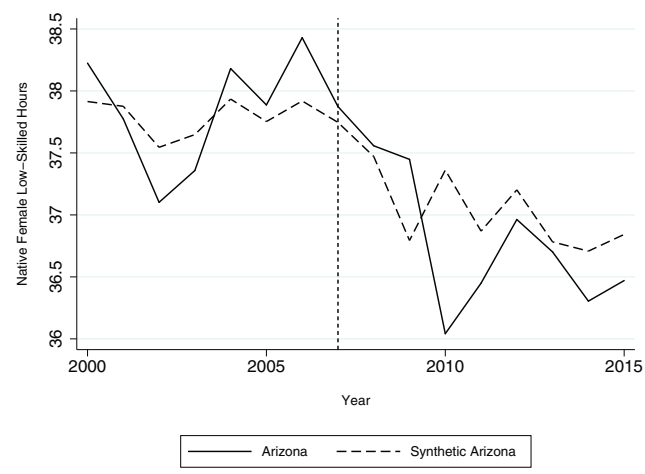

(a) Weekly Hours

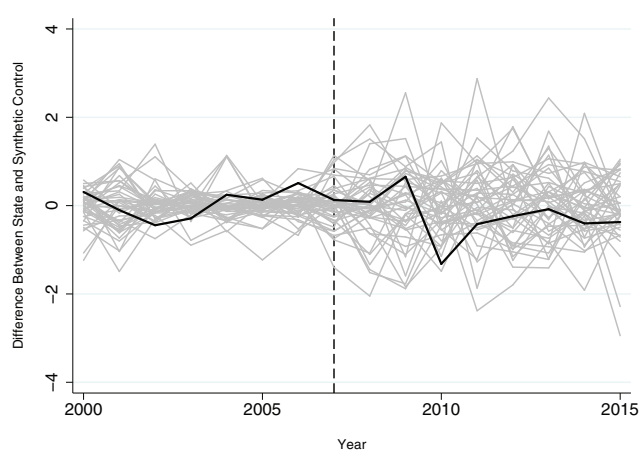

(b) Permutation Test

women's participation rate and average weekly work hours by approximately $1.1 \%$ points and 0.27 h. These reductions, however, are not statistically significant with a $P$-value of 0.200 and 0.333 , respectively.

Previous studies such as Cortes and Tessada (2011) examined the impact of low-skilled immigration on the labor supply of women by their hourly wage quartile, arguing that women with high wages will be more likely to be affected by the reduction in prices of household services resulting from an inflow of low-skilled immigrants. Figures A13-A16 show the impact of LAWA when women are divided into four quartiles based on their hourly wage. The analysis 
shows that there is no evidence that LAWA led to a statistically significant reduction in women's weekly work hours across the four quartiles (Panel B of Table 3).

A recent work by Farrí et al. (2011) also argued that the labor supply of women with family responsibilities would be more affected by immigration. To examine if LAWA had a larger impact on the labor supply of women with family responsibilities, I analyzed whether LAWA affected the labor supply of married women. The results suggest that the labor supply of married women in Arizona were not statistically significantly affected by the passage of LAWA (Panels A and B of Table 3 and Figures A17 and A18).

Although the analyses so far have mainly focused on women, conceptually LAWA might also affect the labor supply of US-born men because they also consumed household services in practice. Despite the negative estimates, suggesting that LAWA reduced the labor supply of US-born men, this decline is not statistically significant at the conventional levels (Panels $C$ and D of Table 3 and Figures A19-A22). ${ }^{9}$

To summarize, there is no evidence that native women's participation rate and average weekly hours decline significantly by the passage of LAWA. These results hold for both lowand high-skilled women measured in terms of their educational attainment and their hourly wage. For the rest of the paper, I examined why LAWA has not led to a reduction in the native female labor supply in Arizona.

\subsection{LAWA, time use, and cost of household services}

The finding that LAWA has not led to a statistically significant decline in the native female labor supply is intriguing, especially because the decline in low-skilled immigrants has been argued to increase the price of household services, which induces women to reduce their participation in the labor market (Cortes, 2008; Cortes and Tessada, 2011). To find out why the female labor supply is relatively unaffected by the passage of LAWA, I began by examining whether LAWA has affected the average time spent on household works among US-born women in Arizona using American Time Use Survey (ATUS) 2003-2015 data. ${ }^{10}$ Since 2003, ATUS has surveyed how people use their time on various activities during a designated 24-hour period. If LAWA increased the cost of household services in Arizona, the average daily time spent on household works among US-born women in Arizona should increase as a response to LAWA. Figures 7 and 8 show the SCM analysis on the average daily time

Figure 7 Native high-skilled female daily time spent on housework, gardening, and caring for children

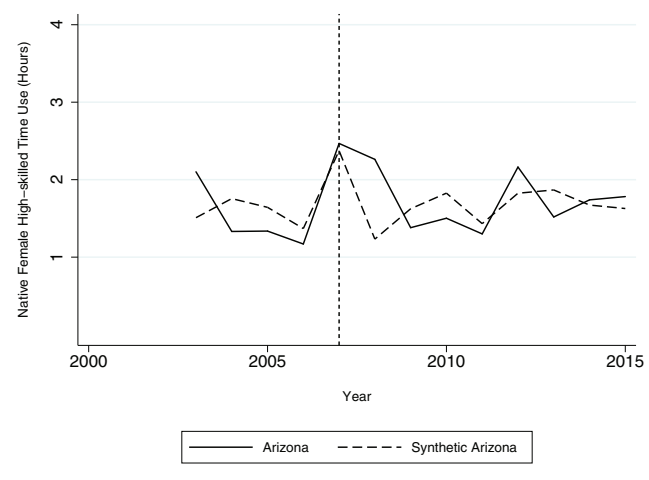

(a) High-skilled Female Daily Time Use

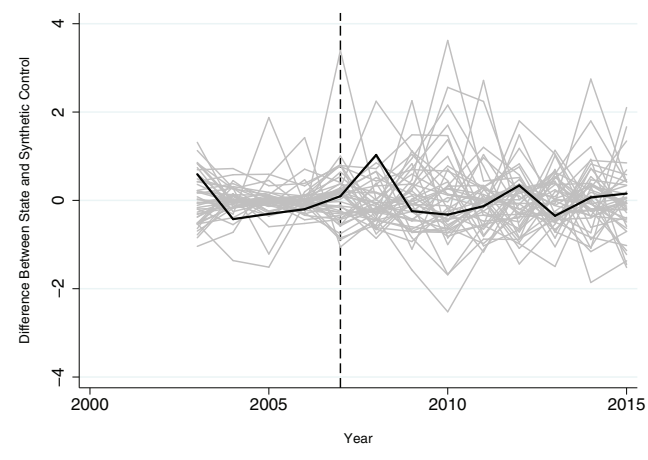

(b) Permutation Test 
spent on household works among high-skilled and low-skilled US-born women, respectively. I found no evidence that LAWA statistically significantly increased the average time use on household works after its adoption in 2007, even among high-skilled US-born women. The difference-in-differences estimate shows that the LAWA increased the average daily time spent on household works by approximately $0.16 \mathrm{~h}$, but this estimate is not statistically significant at the conventional level (Table 4). For low-skill US-born women, the result instead suggests a negative relationship between LAWA and the daily time spent on household works among this group. Qualitatively similar findings were also observed among US-born men (Figures A23 and A24 and Table 4).

The results so far suggest that the labor supply and the time spent on household works among US-born women were not increased by the adoption of LAWA. This finding points out to perhaps a rather surprising hypothesis: LAWA-induced low-skilled immigrant workforce decline did not increase the cost of household services in Arizona. To examine if this is the case, I analyzed whether LAWA increased the cost of household services after its adoption

Figure 8 Native low-skilled female daily time spent on housework, gardening, and caring for children

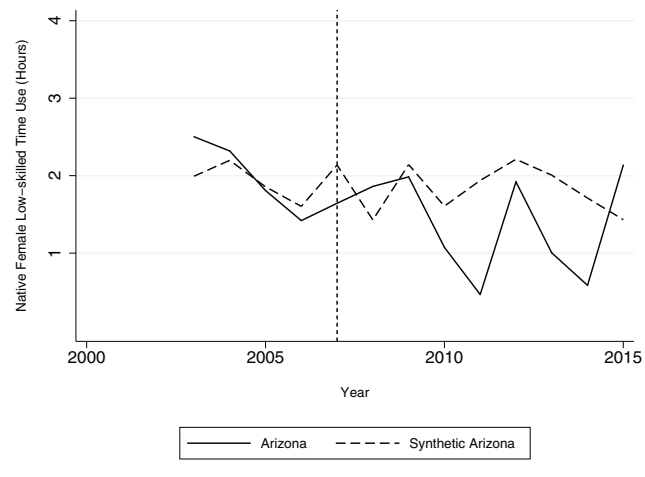

(a) Low-skilled Female Daily Time Use

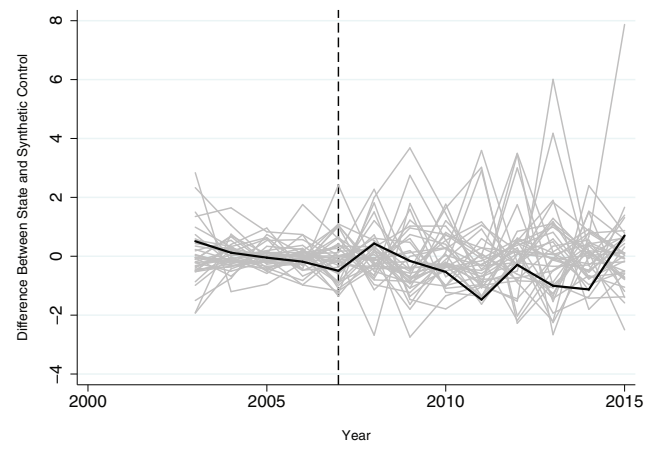

(b) Permutation Test

Table 4 LAWA and native daily time spent on housework, gardening, and caring for children (hours)

\begin{tabular}{|c|c|c|c|c|c|}
\hline & $\begin{array}{l}\text { Avgerage } \\
\text { pre-post } \\
\text { difference in } \\
\text { Arizona }\end{array}$ & $\begin{array}{l}\text { Average pre- } \\
\text { post difference } \\
\text { in synthetic } \\
\text { Arizona }\end{array}$ & $\begin{array}{c}\text { DD } \\
\text { Estimates }\end{array}$ & $\begin{array}{c}\text { Rank, } \\
\text { highest } \\
\text { to lowest }\end{array}$ & $\begin{array}{c}P \text {-value from } \\
\text { one-tailed test, } \\
P(\Delta \geq \Delta A Z)\end{array}$ \\
\hline \multicolumn{6}{|l|}{ Female } \\
\hline High skilled & 0.306 & 0.151 & 0.155 & $11 / 45$ & 0.244 \\
\hline Low skilled & -0.604 & -0.067 & -0.537 & $35 / 38$ & 0.921 \\
\hline \multicolumn{6}{|l|}{ Male } \\
\hline High skilled & 0.215 & 0.096 & 0.119 & $13 / 43$ & 0.302 \\
\hline Low skilled & -0.323 & 0.156 & -0.479 & $34 / 37$ & 0.919 \\
\hline
\end{tabular}

Notes: Estimates based on American Time Use Survey 2003-2015. The donor pool size is represented by the denominator of the rank. The one-tailed test of the significance of the difference-in-difference estimates uses the empirical distribution of the placebo effect estimates of LAWA for states in the donor pool. The pretreatment period is 2003-2006, while the posttreatment period is 2007-2015. Low-skilled females are defined as those with at most high school diploma. High-skilled females are defined as those with college education. LAWA, Legal Arizona Workers Act; DD, difference in differences. 
in 2007 using the average wage in household service occupations as a proxy. Figure 9 shows a SCM analysis on the average hourly wage of workers employed in household service occupations in Arizona before and after the adoption of LAWA. ${ }^{11}$ There is no evidence that LAWA statistically significantly increased the average hourly wage of workers employed in these occupations. The difference-in-differences estimate shows that the average hourly wage in household service occupations increases by approximately 1.2\% (Panel A of Table 5), but this increase is not statistically significant with a $P$-value of 0.400 .

The result that the average hourly wage in household service occupations was not increased by LAWA is surprising, especially because the theory of equilibrium wages based on a standard labor demand and supply framework implies that the reduction in workers in household service occupations should increase the wages of workers in these occupations. The next step of answering why the native female labor supply is relatively unaffected by LAWA would then be to examine whether LAWA led to a significant reduction in the aggregate supply of workers in household service occupations.

\subsection{LAWA and household service occupations' workforce}

The analysis in the previous section shows that the average hourly wage in household services occupation was not statistically significantly increased by the passage of LAWA. One explanation is that a labor market adjustment in Arizona caused the aggregate supply of workers in household service occupations to remain at a similar level after the passage of LAWA in 2007. To examine this, I first analyzed if LAWA has indeed led to a decline in the size of the immigrant workforce in household service occupations. ${ }^{12}$ Figure 10 shows that this is the case. In the absence of LAWA, the number of immigrants is projected to keep increasing to a level above 60,000 workers, while this number declined to approximately 50,000 in actual Arizona. Indeed, the permutation test shows that it is very unlikely that this decline happens simply by chance because there are no other states in which such a deviation between a state and its synthetic control was observed. The difference-in-differences estimate shows that there would be approximately 9,724 additional immigrant workers in household service occupations in the absence of LAWA (Panel B of Table 5).

If the passage of LAWA led to a significant decline in the number of immigrant workers in household service occupations, the theory predicts that LAWA must have increased the number

Figure 9 Wages in household service occupations (housekeepers, gardeners, and childcare workers)

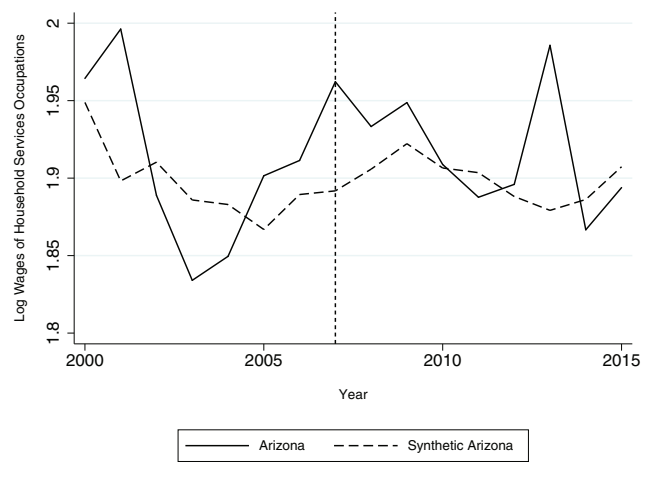

(a) Log Hourly Wages

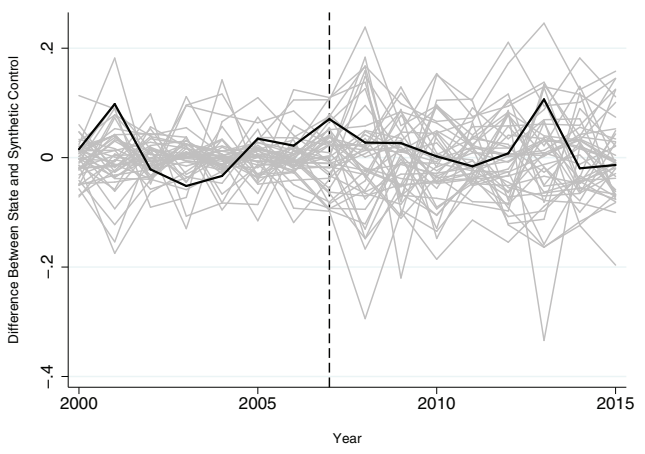

(b) Permutation Test 
Figure 10 Size of immigrant workforce in household service occupations

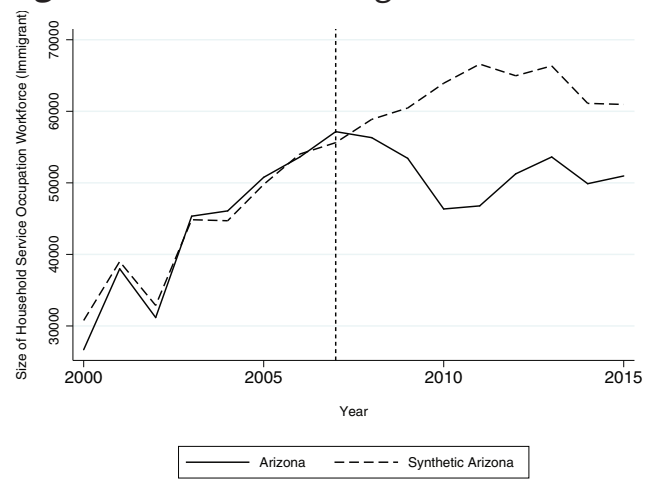

(a) Size of Immigrants Workforce

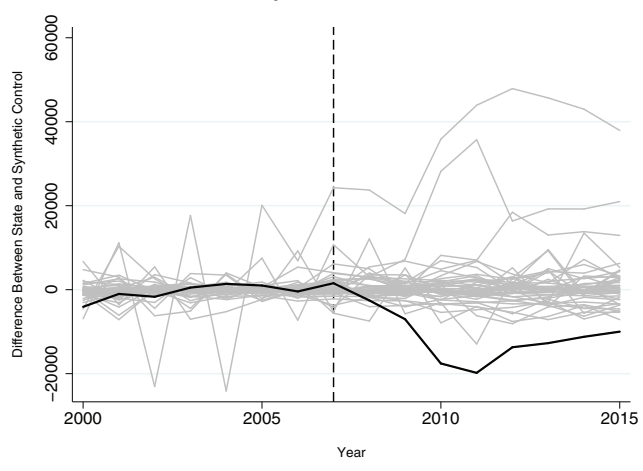

(b) Permutation Test

Table 5 LAWA and household service occupations' wages/supply

\begin{tabular}{|c|c|c|c|c|c|}
\hline & $\begin{array}{l}\text { Average } \\
\text { pre-post } \\
\text { difference } \\
\text { in Arizona }\end{array}$ & $\begin{array}{l}\text { Average pre- } \\
\text { post difference } \\
\text { in synthetic } \\
\text { Arizona }\end{array}$ & $\begin{array}{c}\text { DD } \\
\text { estimates }\end{array}$ & Rank & $\begin{array}{l}P \text {-value } \\
\text { from one- } \\
\text { tailed test }\end{array}$ \\
\hline \multicolumn{6}{|c|}{ A. Price of Household services } \\
\hline Log hourly wages & 0.014 & 0.001 & 0.012 & $\begin{array}{l}18 / 45 \text { (highest } \\
\text { to lowest) }\end{array}$ & 0.400 \\
\hline \multicolumn{6}{|c|}{ B. Household service occupations' supply } \\
\hline $\begin{array}{l}\text { Overall immigrant } \\
\text { supply }\end{array}$ & 10,087 & 19,811 & $-9,724$ & $\begin{array}{l}1 / 44 \text { (lowest } \\
\text { to highest) }\end{array}$ & 0.023 \\
\hline Male immigrant & 5,197 & 12,581 & $-7,383$ & $\begin{array}{l}1 / 44 \text { (lowest } \\
\text { to highest) }\end{array}$ & 0.023 \\
\hline Female immigrant & 4,890 & 9,090 & $-4,200$ & $\begin{array}{l}1 / 44 \text { (lowest } \\
\text { to highest) }\end{array}$ & 0.023 \\
\hline $\begin{array}{l}\text { Overall native } \\
\text { supply }\end{array}$ & 12,391 & 4,755 & 7,636 & $\begin{array}{l}1 / 45 \text { (highest } \\
\text { to lowest) }\end{array}$ & 0.022 \\
\hline Native male & 8,980 & 2,247 & 6,732 & $\begin{array}{l}1 / 45 \text { (highest } \\
\text { to lowest) }\end{array}$ & 0.022 \\
\hline Native female & 3,412 & 754 & 2,658 & $\begin{array}{l}6 / 45 \text { (highest } \\
\text { to lowest) }\end{array}$ & 0.133 \\
\hline $\begin{array}{l}\text { Overall } \\
\text { (immigrant + } \\
\text { native) supply }\end{array}$ & 22,478 & 22,174 & 304 & $\begin{array}{l}27 / 45 \text { (lowest } \\
\text { to highest) }\end{array}$ & 0.600 \\
\hline
\end{tabular}

Notes: Estimates based on Integrated Public Use Microdata Series (IPUMS) 5\% 2000 Census and 2001-2015 ACS. The donor pool size is represented by the denominator of the rank. The one-tailed test of the significance of the difference-in-difference estimates uses the empirical distribution of the placebo effect estimates of LAWA for states in the donor pool. The pretreatment period is 2000-2006, while the posttreatment period is 2007-2015. LAWA, Legal Arizona Workers Act; DD, difference in differences; ACS, American Community Survey.

of native workers in these occupations as to leave the average wage in these occupations unaffected by LAWA. Figure 11 shows that this is indeed the case. After LAWA was adopted in 2007, the increase in native workers in household service occupations is significantly larger relative to what was projected in the absence of it. The difference-in-differences estimate shows that the number of natives in these occupations would be lower by approximately 7,636 workers in the absence of LAWA (Panel B of Table 5). Comparing this estimate with that of immigrant 
workers, a large share of the impact of LAWA ( 75\%) is compensated for by the increase in native workers. A rather interesting finding is that this increase is driven by US-born men. This result mainly reflects the finding that LAWA induced more male immigrants in household service occupations to leave (and not coming to) Arizona after its passage in 2007 (Panel B of Table 5 and Figures A25-A28).

To see if this increase in native workers in household service occupations is indeed large enough to leave the size of the workforce in these occupations unaffected by the passage of LAWA, I repeated the analysis for the overall number of workers (foreign and US born) in these occupations. Figure 12 shows that the overall number of workers in household service occupations is relatively unaffected by the passage of LAWA. The difference-in-differences estimate supports the evidence from the graphical observation that the size of household service occupations workforce is not statistically significantly affected by LAWA (Panel B of Table 5).

A question remains to be answered: why LAWA increased the number of native workers in household service occupations? One possible answer to this may lie from the fact that native workers have a relative advantage in occupations that require higher communication/interactive task compared to foreign-born workers. Recent works in the immigration literature have documented the role of low-skilled immigration in nudging US workers toward occupations that require higher communication proficiency to reduce downward pressure on their wages (Peri and Sparber, 2009; Peri and Sparber, 2011). As LAWA shrinks the low-skilled immigrant workforce in Arizona, there is less incentive for natives to specialize in occupations that require

Figure 11 Size of native workforce in household service occupations

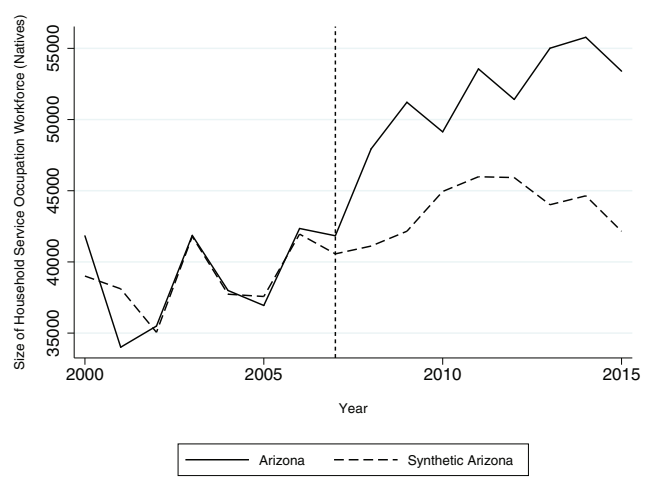

(a) Size of Natives Workforce

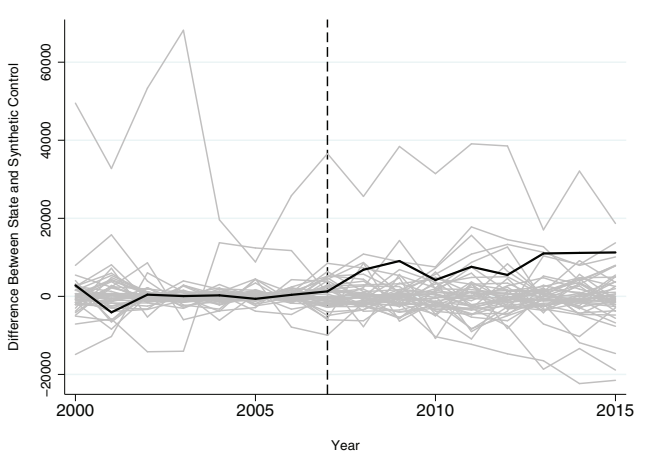

(b) Permutation Test

Figure 12 Size of household service occupations workforce

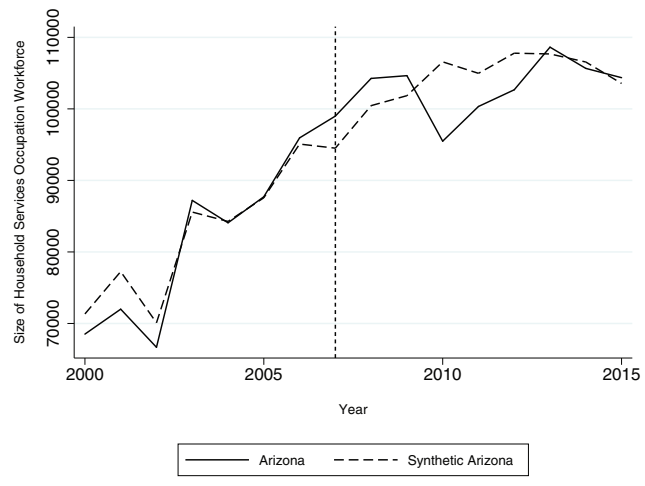

(a) Size of Workforce

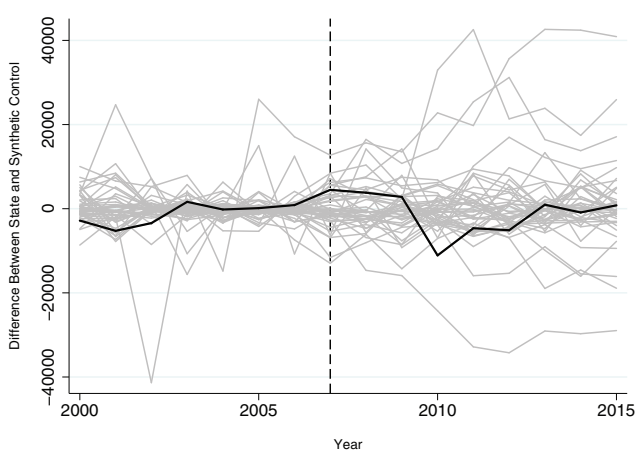

(b) Permutation Test 
higher communication skill. To further analyze the possibility of natives' occupational downgrading, I examined the effect of LAWA on the occupational income score of low-skilled natives separated by gender (Panel A of Table 6 and Figures A29 and A30). ${ }^{13}$ The analysis indeed shows evidence that occupational income score of low-skilled US-born males decreases due to LAWA, suggesting that these workers would be in a higher paid occupation in the absence of the policy. The difference-in-differences estimate shows that LAWA reduces the occupational income score of low-skilled US-born males by 0.37 (1.34\% relative to pre-LAWA score). This finding is similar to that of Lee et al. (2019) who also found evidence of occupational downgrading by US natives following Mexican repatriations in the 1930s. ${ }^{14}$

\subsection{Sensitivity checks}

The key finding in this paper is that LAWA reduced the number of foreign-born workers in household service occupations, but this decline was compensated by the increase in native workers in these occupations, leaving the cost of household services and thus the labor supply of US-born women relatively unaffected by the passage of LAWA. In this section, I examined whether my main finding holds under alternative specifications.

As noted by Abadie et al. (2010), another way to conduct permutation test is to examine whether the ratio of post/pre-LAWA root mean-squared prediction error (RMSPE) between Arizona and its synthetic control is larger relative to other placebo runs. The main reason for conducting the permutation test this way is to take into account the quality of the pretreatment match of placebo runs. Figure 13a shows the test for the size of the immigrant workforce in household service occupations. The ratio for Arizona clearly stands out: there are no other placebo runs in which the post/pre-LAWA RMSPE ratio is larger than Arizona. The probability of obtaining the post/pre-LAWA RMSPE ratio that is as large as Arizona's is 1/45 =0.022.

Table 6 LAWA and occupation income score

\begin{tabular}{|c|c|c|c|c|c|}
\hline & $\begin{array}{l}\text { Average } \\
\text { pre-post } \\
\text { difference in } \\
\text { Arizona }\end{array}$ & $\begin{array}{l}\text { Average pre- } \\
\text { post difference } \\
\text { in synthetic } \\
\text { Arizona }\end{array}$ & $\begin{array}{c}\text { DD } \\
\text { estimates }\end{array}$ & Rank & $\begin{array}{c}\text { P-value } \\
\text { from one- } \\
\text { tailed test }\end{array}$ \\
\hline \multicolumn{6}{|c|}{ A. Occupational income score } \\
\hline $\begin{array}{l}\text { Low-skilled } \\
\text { native male }\end{array}$ & -0.844 & -0.474 & -0.369 & $\begin{array}{l}\text { 3/45 (lowest } \\
\text { to highest) }\end{array}$ & 0.067 \\
\hline $\begin{array}{l}\text { Low-skilled } \\
\text { native female }\end{array}$ & -0.426 & -0.525 & 0.099 & $\begin{array}{l}27 / 45 \text { (lowest } \\
\text { to highest) }\end{array}$ & 0.600 \\
\hline \multicolumn{6}{|c|}{ B. Employment rate } \\
\hline $\begin{array}{l}\text { Low-skilled } \\
\text { native male }\end{array}$ & -0.101 & -0.066 & -0.035 & $\begin{array}{c}42 / 45 \text { (highest } \\
\text { to lowest) }\end{array}$ & 0.933 \\
\hline $\begin{array}{l}\text { Low-skilled } \\
\text { native female }\end{array}$ & -0.050 & -0.027 & -0.023 & $\begin{array}{l}\text { 42/45 (highest } \\
\text { to lowest) }\end{array}$ & 0.933 \\
\hline
\end{tabular}

Notes: Estimates based on Integrated Public Use Microdata Series (IPUMS) 5\% 2000 Census and 2001-2015 ACS. The donor pool size is represented by the denominator of the rank. The one-tailed test of the significance of the difference-in-difference estimates uses the empirical distribution of the placebo effect estimates of LAWA for states in the donor pool. The pretreatment period is 2000-2006, while the posttreatment period is 2007-2015. LAWA, Legal Arizona Workers Act; DD, difference in differences; ACS, American Community Survey. 
Figure 13b shows the corresponding figure for the size of the native workforce in household service occupations. The result in the previous section holds; the probability of obtaining the post/pre-LAWA RMSPE ratio that is as large as Arizona's is 4/45 $=0.089$.

Another concern to the validity of the results presented in this study is the potential existence of spillover effects. For example, if the adoption of LAWA in Arizona had a positive effect on the size of the immigrant workforce in household service occupations in the neighboring states, then the synthetic control would provide an overestimate of the counterfactual size of the immigrant workforce in Arizona. ${ }^{15}$ To examine if the results are driven by spillover effects on the neighboring states, I redid the analysis of the size of immigrant and native workforce in household service occupations excluding Arizona's neighboring states from the donor pool (i.e., California, New Mexico, Colorado, Utah, and Nevada). The results hold qualitatively and are available upon request.

As an additional check, I conducted a leave-one-out test to see whether one of the donor states is driving the results. That is, I iteratively reestimated the model to construct a synthetic Arizona omitting one of the donor states that receive positive weight from the donor pool in each iteration. For the size of the native workforce in household service occupations, the leaveone-out synthetic controls closely match the original synthetic Arizona, implying the robustness of the original synthetic Arizona (Figure 14a). For the size of the immigrant workforce in household service occupations, however, the decline is the smallest when Texas is excluded from the donor pool (Figure 14b). Nonetheless, the estimate is still substantive: LAWA reduced

Figure 13 Robustness check: taking into account pre-treatment match quality

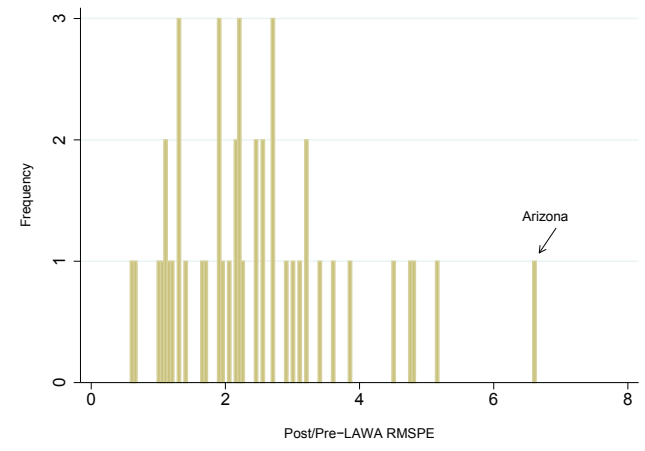

(a) Size of Immigrant Workforce in Household Service Occupations

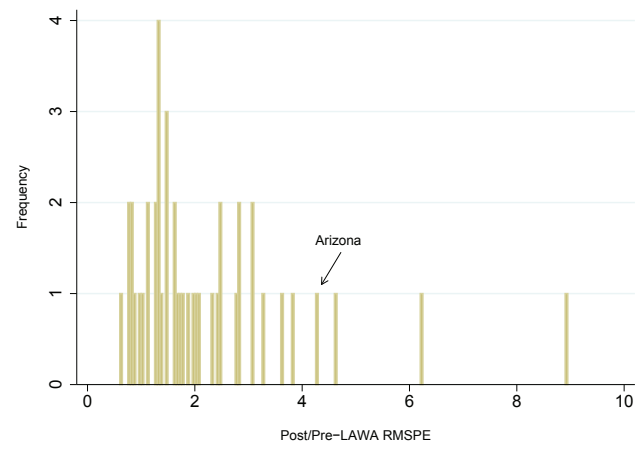

(b) Size of Native Workforce in Household Service Occupations

Figure 14 Robustness check: leave-one-out test

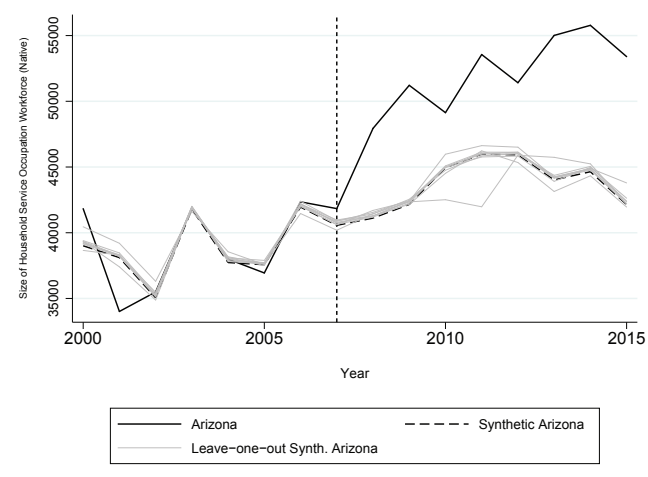

(a) Size of Native Workforce in Household Service Occupations

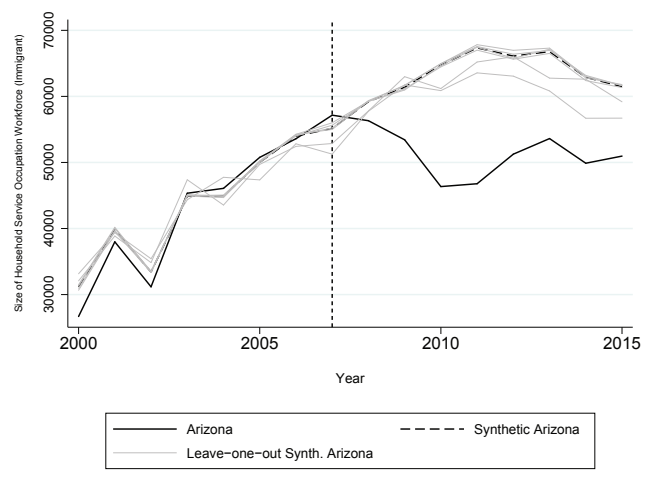

(b) Size of Immigrant Workforce in Household Service Occupations 
the size of the immigrant workforce by approximately 6,859 workers. This corresponds to $13 \%$ decline relative to its level in 2006.

Finally, I checked the robustness of the main findings by substantially narrowing the postLAWA window, limiting the potential effects of other anti-immigration policies that occurred after 2007, such as SB 1070. The work by Amuedo-Dorantes and Lozano (2015) suggested that SB 1070 had a negligible impact on likely unauthorized population in Arizona. Nonetheless, the impact of LAWA can be further isolated by excluding the years after 2010 from the analysis. The results of this exercise are reported in Table 7, and the main findings hold under this alternative specification.

\section{Conclusion}

The influx of low-skilled immigrants has been argued to reduce the price of household services and alter the optimal time allocation between household production and market work for women (e.g., Cortes, 2008; Cortes and Tessada, 2011; Barone and Mocetti, 2011). As such, policies that lead to a decline in low-skilled immigrants may have an unintended consequence of reducing women's participation in the labor market.

In this study, I examined the impact of the LAWA of 2007, which requires all employers in Arizona to verify if a worker is authorized to work in the United States through the federal

Table 7 Sensitivity check - excluding post-2010

\begin{tabular}{|c|c|c|c|c|c|}
\hline & $\begin{array}{l}\text { Average } \\
\text { pre-post } \\
\text { difference } \\
\text { in Arizona }\end{array}$ & $\begin{array}{l}\text { Average pre- } \\
\text { post difference } \\
\text { in synthetic } \\
\text { Arizona }\end{array}$ & $\begin{array}{c}\text { DD } \\
\text { estimates }\end{array}$ & Rank & $\begin{array}{l}\text { P-value } \\
\text { from one- } \\
\text { tailed test }\end{array}$ \\
\hline \multicolumn{6}{|c|}{ A. Native female participation rate } \\
\hline High skilled & 0.017 & 0.014 & 0.004 & $\begin{array}{l}\text { 30/45 (lowest } \\
\text { to highest) }\end{array}$ & 0.667 \\
\hline Low skilled & -0.011 & -0.007 & -0.004 & $\begin{array}{l}15 / 45 \text { (lowest } \\
\text { to highest) }\end{array}$ & 0.333 \\
\hline \multicolumn{6}{|c|}{ B. Native female hours per week } \\
\hline High skilled & -0.343 & -0.201 & -0.142 & $\begin{array}{l}12 / 45 \text { (lowest } \\
\text { to highest) }\end{array}$ & 0.267 \\
\hline Low skilled & -0.620 & -0.455 & -0.165 & $\begin{array}{l}17 / 45 \text { (lowest } \\
\text { to highest) }\end{array}$ & 0.378 \\
\hline \multicolumn{6}{|c|}{ C. Household service occupations } \\
\hline $\begin{array}{l}\text { Number of } \\
\text { immigrants }\end{array}$ & 11,650 & 17,435 & $-5,785$ & $\begin{array}{l}1 / 44 \text { (lowest to } \\
\text { highest) }\end{array}$ & 0.023 \\
\hline $\begin{array}{l}\text { Number of } \\
\text { natives }\end{array}$ & 8,891 & 3,451 & 5,440 & $\begin{array}{l}3 / 45 \text { (highest } \\
\text { to lowest) }\end{array}$ & 0.067 \\
\hline
\end{tabular}

Notes: Estimates based on Integrated Public Use Microdata Series (IPUMS) 5\% 2000 Census and 2001-2015 ACS. The donor pool size is represented by the denominator of the rank. The one-tailed test of the significance of the difference-in-difference estimates uses the empirical distribution of the placebo effect estimates of LAWA for states in the donor pool. The pretreatment period is 2000-2006, while the posttreatment period is 2007-2010. Lowskilled females are defined as those with at most high school diploma. High-skilled females are defined as those with college education. DD, difference in differences; ACS, American Community Survey; LAWA, Legal Arizona Workers Act. 
E-Verify system, on the native female labor supply. The analysis yields a few main results. First, the number of low-skilled immigrant workers in the labor force shrank significantly in Arizona due to the passage of LAWA. I estimated that the share of the low-skilled immigrant workforce in Arizona would be higher by approximately 1.1\% points in the absence of LAWA. Second, I failed to find evidence that LAWA significantly affected US-born women's labor supply and the time spent on household works in Arizona. Finally, the finding that LAWA did not significantly affect the native female labor supply is driven partly by an increase in native workers in household service occupations due to the implementation of LAWA, which offset the decline in immigrants in these occupations and caused the cost of household services to be relatively uninfluenced by the passage of LAWA. This increase in native workers in household service occupations is consistent with the relative task redistribution argument in which low-skilled immigration nudges US workers toward occupations that require higher communication skill to reduce downward pressure on their wages (Peri and Sparber, 2009; Peri and Sparber, 2011).

The results presented in this study thus suggest that policies that lead to a decline in the low-skilled immigrant workforce may not necessarily decrease US-born women's participation in the labor market. In the case of Arizona, an increase in native workers in household service occupations due to LAWA leaves the aggregate supply of workers in the household service occupations unaffected, resulting in no statistically significant effect on women's labor supply. It is worth noting that the findings presented in this study may not necessarily contradict the work of Cortes (2008) and Cortes and Tessada (2011). Instead, the findings of this study support the argument by Clemens et al. (2018) and Lee et al. (2019) that the labor market effects of an increase in low-skilled immigrants might not be symmetric as reducing it through immigration restriction policy.

\section{Declarations}

\section{Availability of data and material}

The datasets used and/or analyzed during the current study are available from the corresponding author on reasonable request.

\section{Competing interests}

The author declares that he has no competing interests.

\section{Funding}

Not applicable.

\section{Author's contributions}

Not applicable.

\section{Acknowledgments}

I would like to thank Joseph Cummins, Michael Bates, Steven Helfand, and all who have provided comments and suggestions for the earlier version of the paper. I would also like to thank the anonymous referee and the editor for the constructive suggestions. All mistakes are my own.

\section{References}

Abadie, A.; A. Diamond; J. Hainmueller (2010): Synthetic Control Methods for Comparative Case Studies: Estimating the Effect of California's Tobacco Control Program. Journal of the American statistical Association 105(490), 493-505.

Abadie, A.; A. Diamond; J. Hainmueller (2015): Comparative Politics and the Synthetic Control Method. American Journal of Political Science 59(2), 495-510. 
Abadie, A.; J. Gardeazabal (2003): The Economic Costs of Conflict: A Case Study of the Basque Country. The American Economic Review 93(1), 113-132.

Acemoglu, D.; D.H. Autor; D. Lyle (2004): Women, War, and Wages: The Effect of Female Labor Supply on the Wage Structure at Midcentury. Journal of political Economy 112(3), 497-551.

Amuedo-Dorantes, C.; F. Lozano (2015): On the Effectiveness of sb1070 in Arizona. Economic Inquiry 53(1), 335-351.

Barone, G.; S. Mocetti (2011): With a Little Help from Abroad: the Effect of Low-Skilled Immigration on the Female Labour Supply. Labour Economics 18(5), 664-675.

Bohn, S.; M. Lofstrom; S. Raphael (2014): Did the 2007 Legal Arizona Workers Act Reduce the State's Unauthorized Immigrant Population? Review of Economics and Statistics 96(2), 258-269.

Bohn, S.; M. Lofstrom; S. Raphael (2015): Do E-Verify Mandates Improve Labor Market Outcomes of LowSkilled Native and Legal Immigrant Workers? Southern Economic Journal 81(4), 960-979.

Cattaneo, C.; C.V. Fiorio; G. Peri (2015): What Happens to the Careers of European Workers When Immigrants Take Their Jobs? Journal of Human Resources 50(3), 655-693.

Chalfin, A.; M. Deza (2018). New Evidence on Mexican Immigration and Crime in the United States: Evidence from a Natural Experiment in Immigration Enforcement.

Clemens, M.A.; E.G. Lewis; H.M. Postel (2018): Immigration Restrictions as Active Labor Market Policy: Evidence from the Mexican Bracero Exclusion. American Economic Review 108(6), 1468-14687.

Cooper, B.; K. O'Neil (2005): Lessons from the Immigration Reform and Control Act of 1986. Migration Policy Institute Policy Brief, 3.

Cortes, P.; J. Pan (2013): Outsourcing Household Production: Foreign Domestic Workers and Native Labor Supply in Hong Kong. Journal of Labor Economics 31(2), 327-371.

Cortes, P.; J. Tessada (2011): Low-Skilled Immigration and the Labor Supply of Highly Skilled Women. American Economic Journal: Applied Economics 3(3), 88-123.

Cortes, P. (2008): The Effect of Low-Skilled Immigration on us Prices: Evidence from CPI Data. Journal of political Economy 116(3), 381-422.

Farré, L.; L. González; F. Ortega (2011): Immigration, Family Responsibilities and the Labor Supply of Skilled Native Women. The B.E. Journal of Economic Analysis \& Policy 11(1), 34.

Gunadi, C. (2018): Does Stricter Immigration Policy Affect College Enrollment and Public-Private School Choice of Natives? IZA Journal of Development and Migration 8(1), 25.

Hoekstra, M.; S. Orozco-Aleman (2017): Illegal immigration, state law, and deterrence. American Economic Journal: Economic Policy 9(2), 228-252.

Kaul, A.; S. Klößner; G. Pfeifer; M. Schieler (2015): Synthetic Control Methods: NEVER use all Pre-Intervention Outcomes as Economic Predictors. Unpublished. http://www.oekonometrie.uni-saarland.de/papers/ SCM_Predictors.pdf.

Lee, J., G. Peri; V. Yasenov (2019): The Labor Market Effects of Mexican Repatriations: Longitudinal Evidence from the 1930s. Technical Report, National Bureau of Economic Research.

Liou, W.; T.J. Halliday (2016): By the Time I get to Arizona: Estimating the Impact of the Legal Arizona Workers Act on Migrant Outflows. Economics Bulletin 36(4), 2526-2534.

Orrenius, P.M.; M. Zavodny (2015): The Impact of E-Verify Mandates on Labor Market Outcomes. Southern Economic Journal 81(4), 947-959.

Orrenius, P.M.; M. Zavodny (2016): Do State Work Eligibility Verification Laws Reduce Unauthorized Immigration? IZA Journal of Migration 5(1), 5.

Peri, G.; A. Romiti; M. Rossi (2013): Immigrants, Household Production and Women's Retirement.

Peri, G.; C. Sparber (2009): Task Specialization, Immigration, and Wages. American Economic Journal: Applied Economics 1(3), 135-169.

Peri, G.; C. Sparber (2011): Highly Educated Immigrants and Native Occupational Choice. Industrial Relations: A Journal of Economy and Society 50(3), 385-411.

Peri, G.; V. Yasenov (2018): The Labor Market Effects of A Refugee Wave: Synthetic Control Method Meets the Mariel Boatlift. Journal of Human Resources, page 0217_8561R1.

Ruggles, S.; K. Genadek; R. Goeken; J. Grover; M. Sobek (2015): Integrated Public use Microdata Series: Version 6.0 [machine-readable database). Minneapolis: University of Minnesota.

Westat (2009): Findings of the E-Verify Program Evaluation. Rockville, MD: Westat. 


\section{Appendix}

Figure A1 Alabama universal e-verify and size of low-skilled immigrant workforce

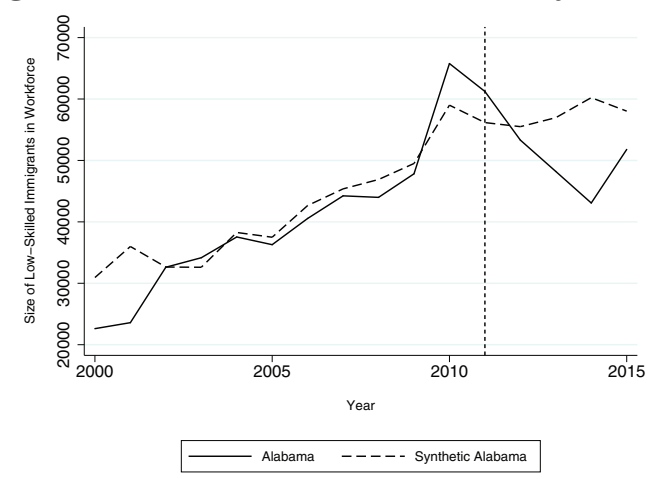

(a) Size of Low-Skilled Immigrant Workforce

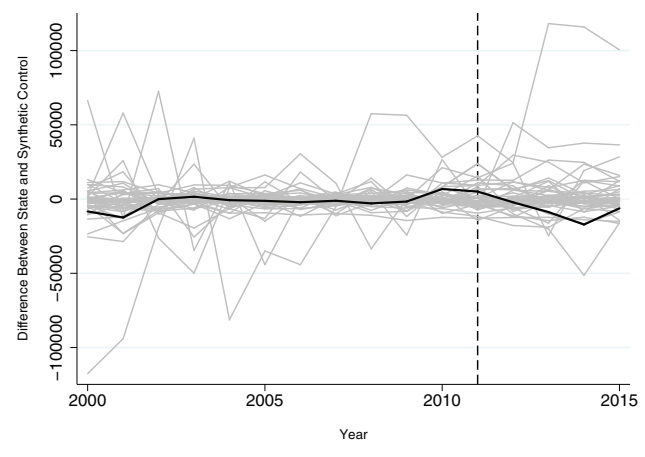

(b) Permutation Test

Figure A2 Alabama universal e-verify and share of low-skilled immigrants in workforce

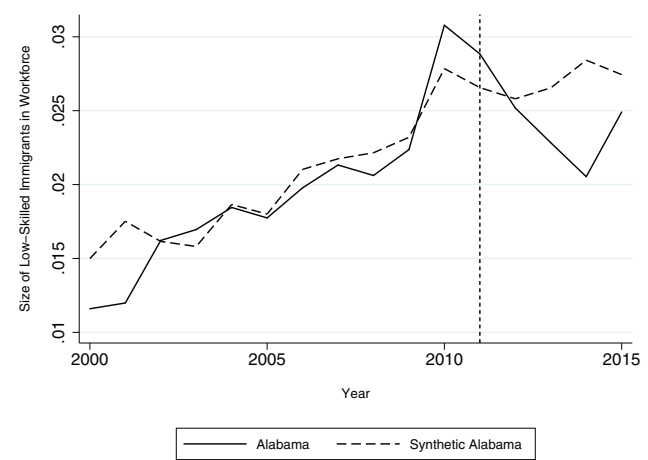

(a) Share of Low-Skilled Immigrant in Workforce

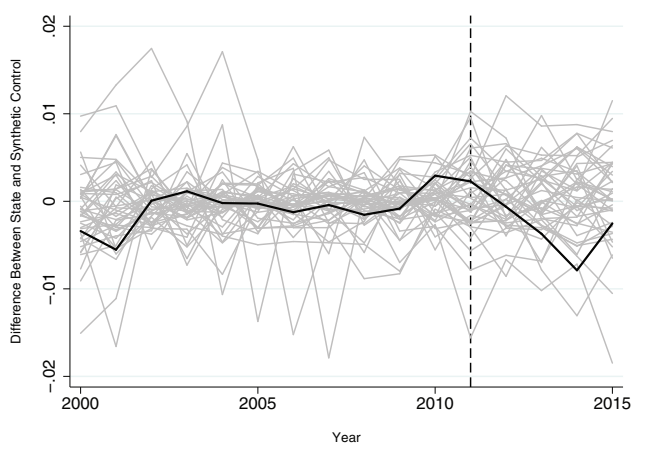

(b) Permutation Test

Figure A3 Georgia universal e-verify and size of low-skilled immigrant workforce

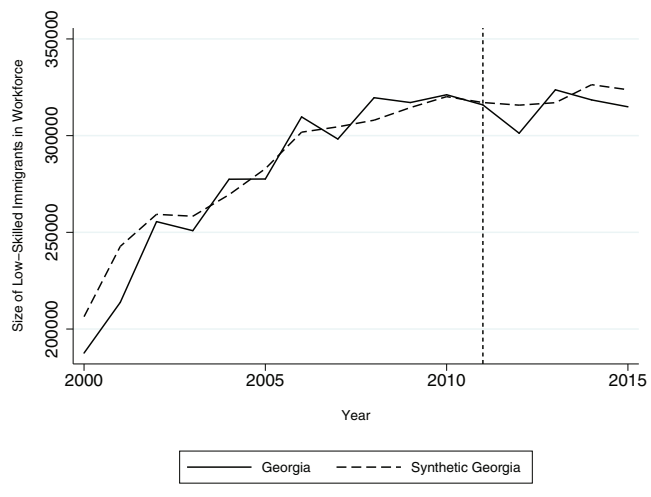

(a) Size of Low-Skilled Immigrant Workforce

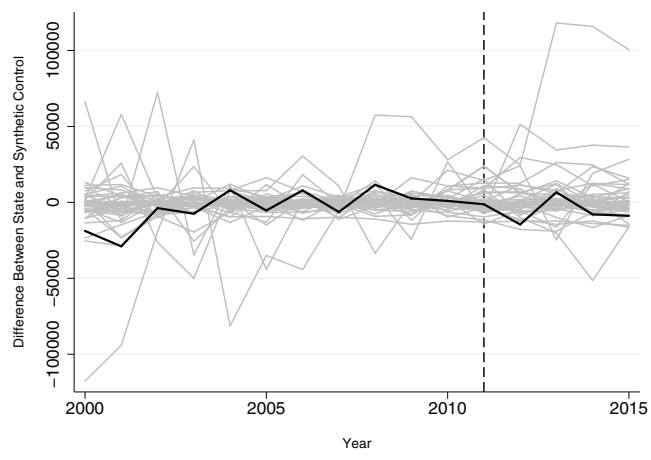

(b) Permutation Test 
Figure A4 Georgia universal e-verify and share of low-skilled immigrants in workforce

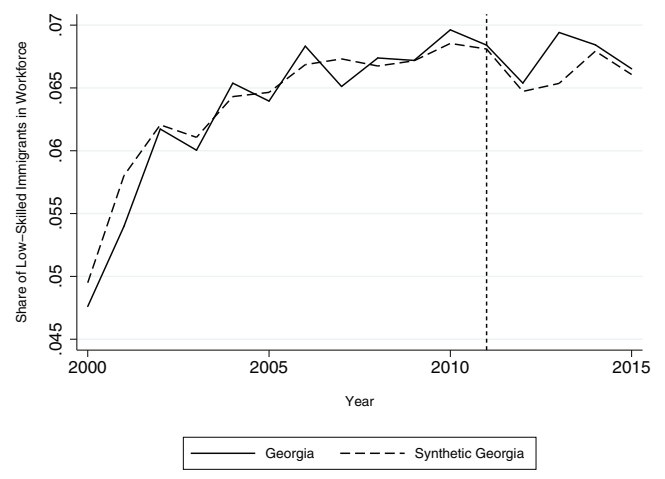

(a) Share of Low-Skilled Immigrant in Workforce

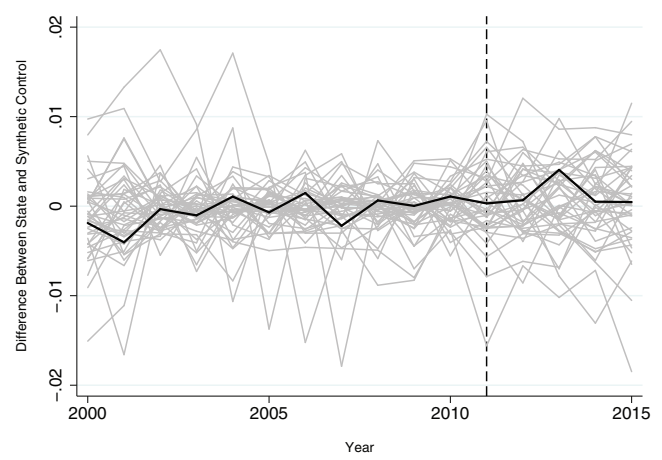

(b) Permutation Test

Figure A5 Mississippi universal e-verify and size of low-skilled immigrant workforce

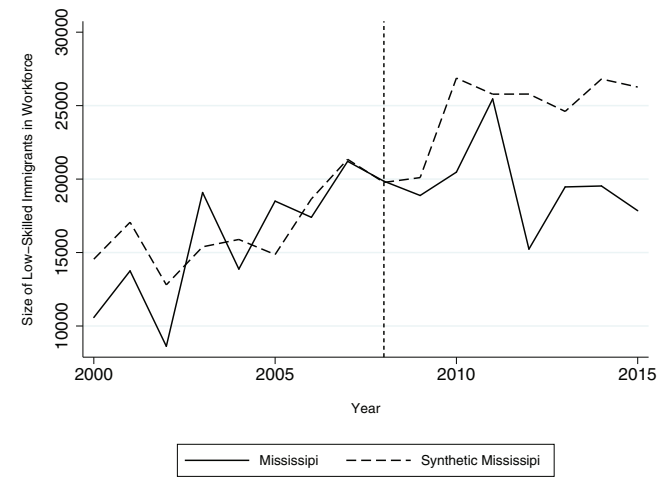

(a) Size of Low-Skilled Immigrant Workforce

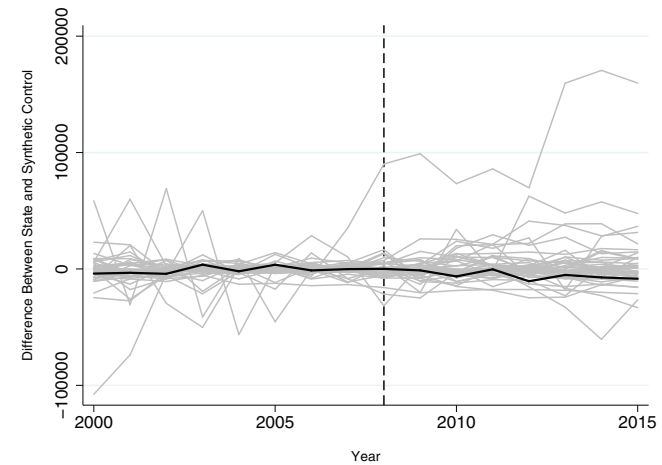

(b) Permutation Test

Figure A6 Mississippi universal e-verify and share of low-skilled immigrants in workforce

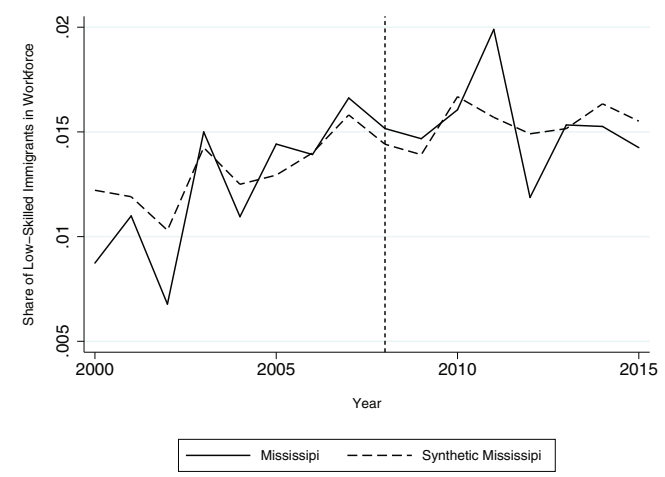

(a) Share of Low-Skilled Immigrant in Workforce

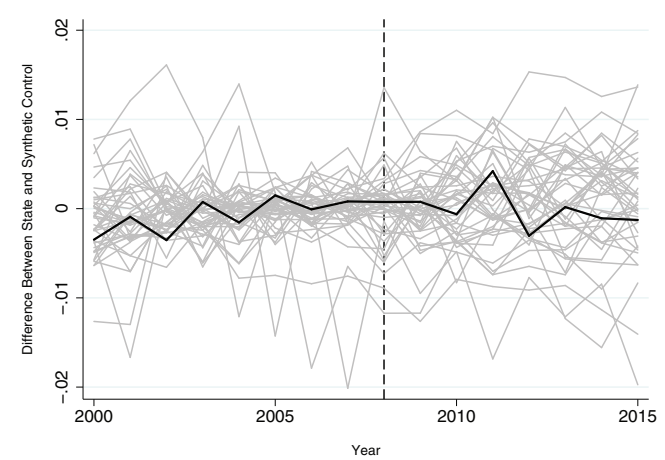

(b) Permutation Test 
Figure A7 North carolina universal e-verify and size of low-skilled immigrant workforce

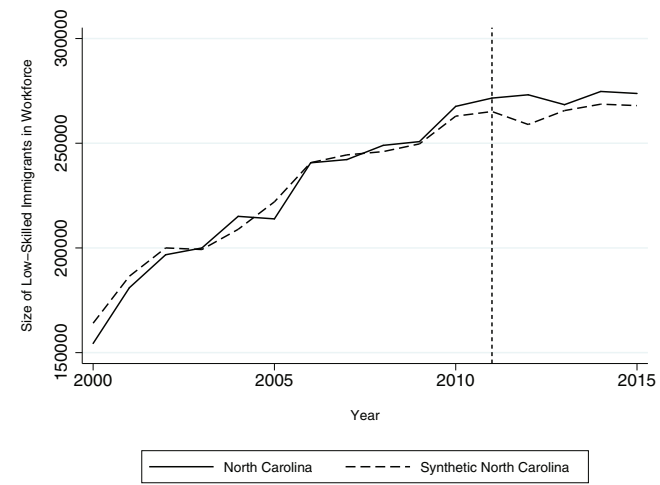

(a) Size of Low-Skilled Immigrant Workforce

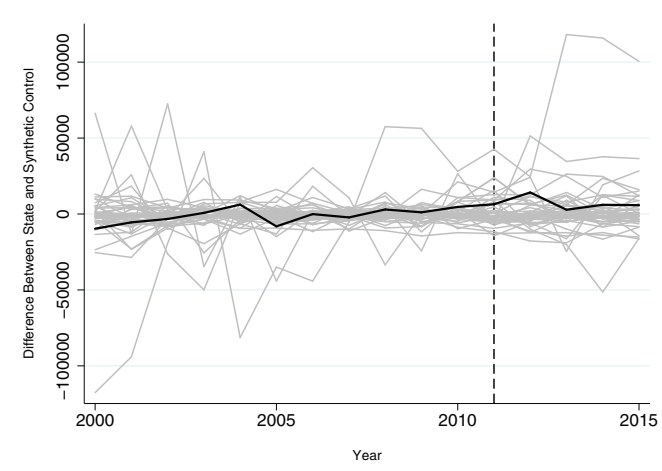

(b) Permutation Test

Figure A8 North carolina universal e-verify and share of low-skilled immigrants in workforce

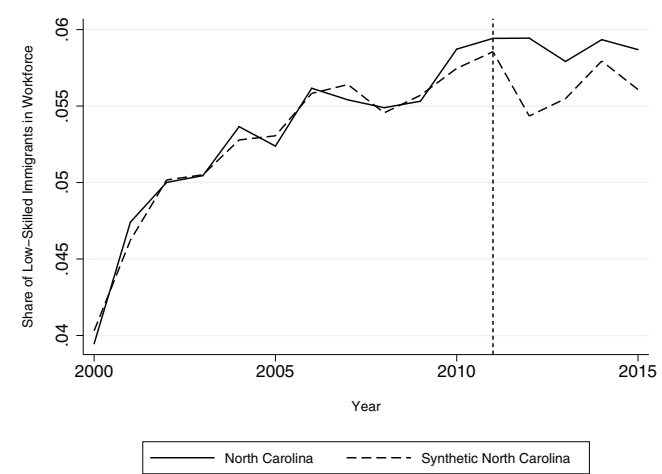

(a) Share of Low-Skilled Immigrant in Workforce

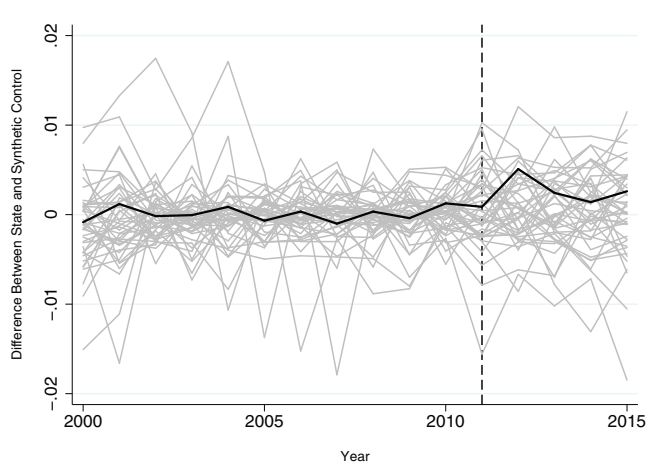

(b) Permutation Test

Figure A9 South carolina universal e-verify and size of low-skilled immigrant workforce

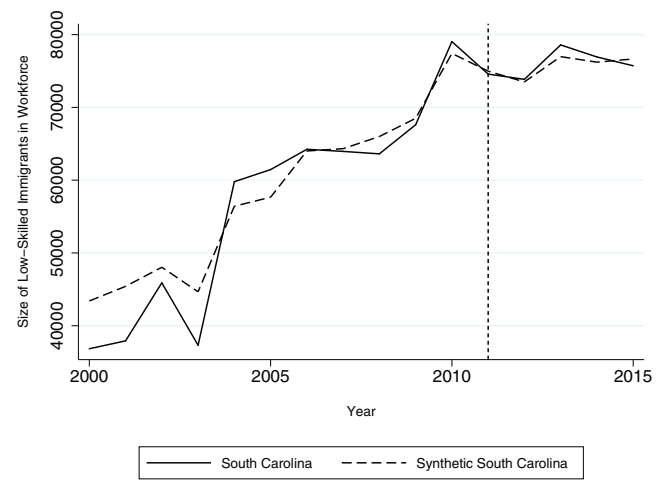

(a) Size of Low-Skilled Immigrant Workforce

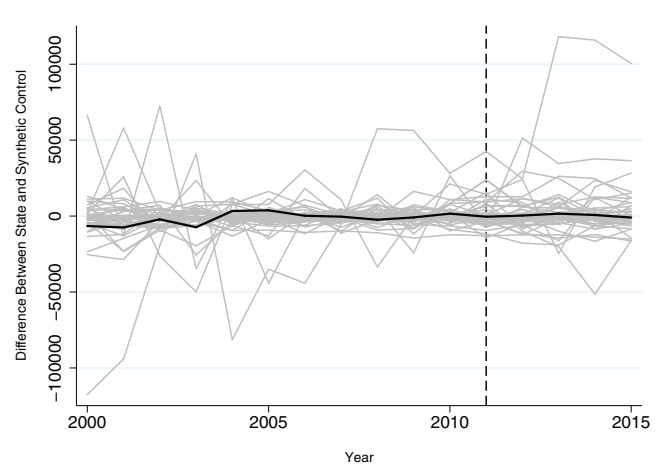

(b) Permutation Test 
Figure A10 South carolina universal e-verify and share of low-skilled immigrants in workforce

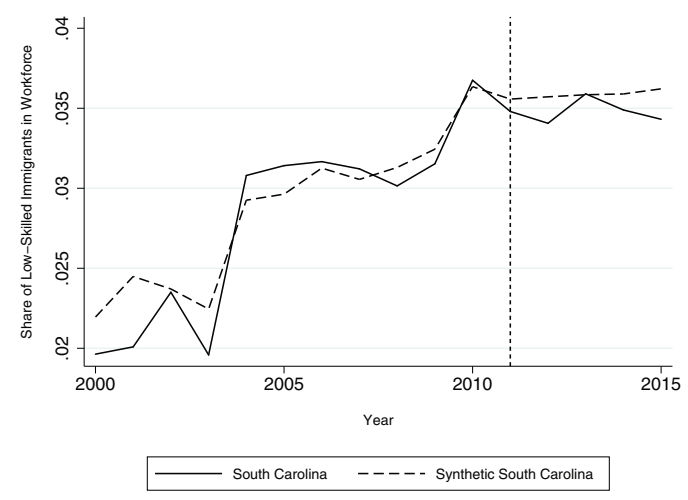

(a) Share of Low-Skilled Immigrant in Workforce

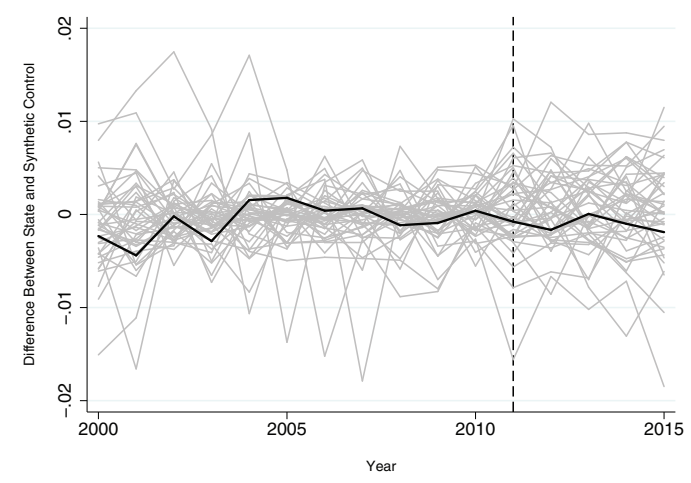

(b) Permutation Test

Figure A11 Utah universal e-verify and size of low-skilled immigrant workforce

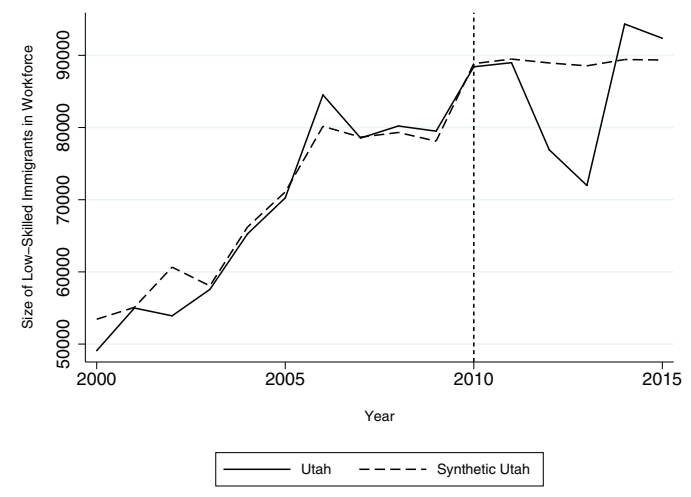

(a) Size of Low-Skilled Immigrant Workforce

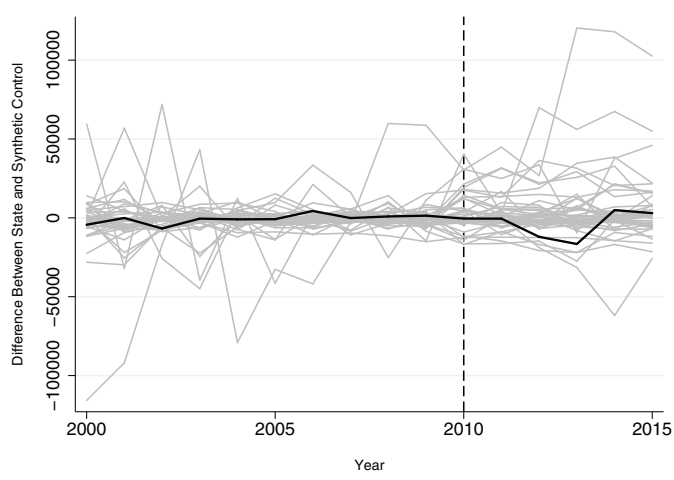

(b) Permutation Test

Figure A12 Utah universal e-verify and share of low-skilled immigrants in workforce

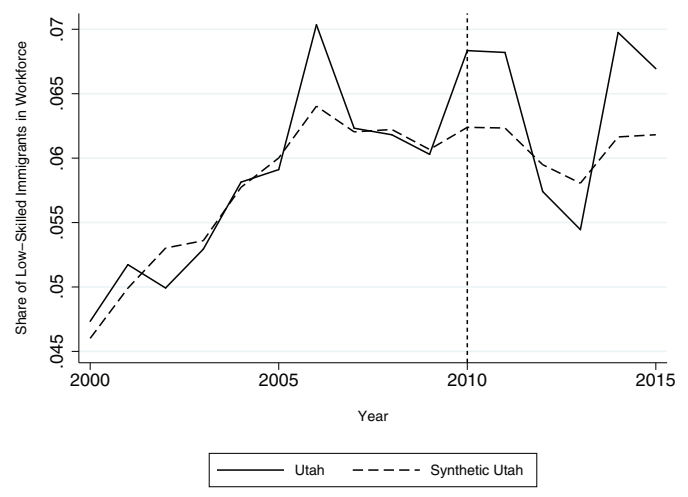

(a) Share of Low-Skilled Immigrant in Workforce

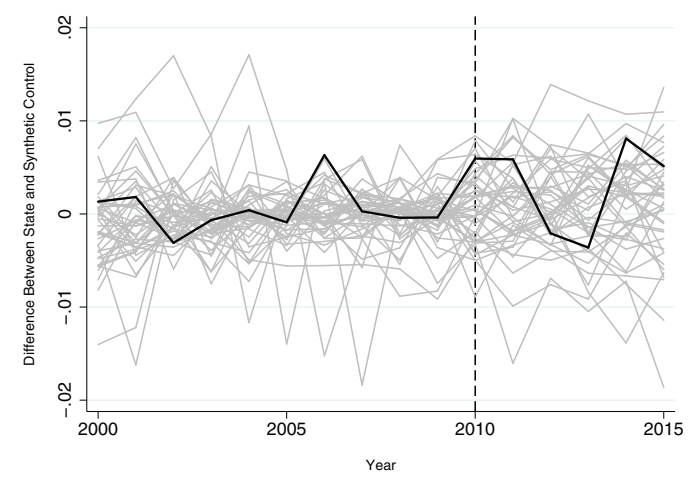

(b) Permutation Test 
Figure A13 Native female weekly hours (0-25 wage pct. | hours $>0)$

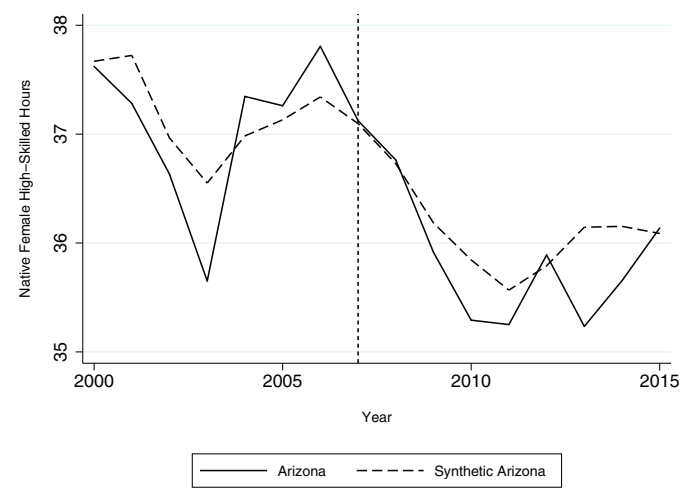

(a) 0-25 Wage pct.

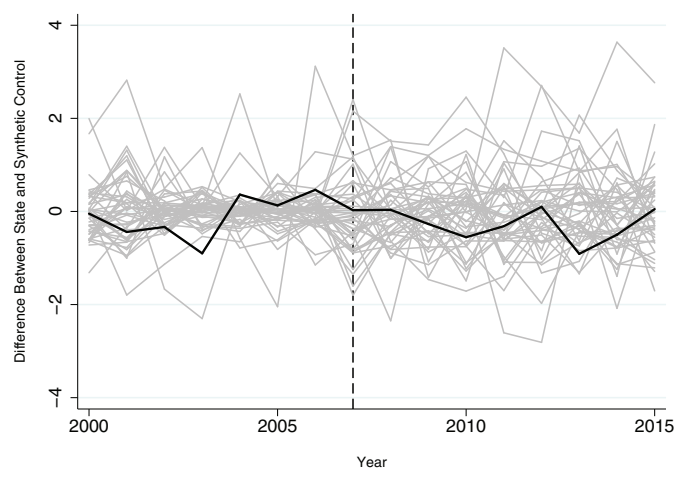

(b) Permutation Test

Figure A14 Native female weekly hours (25-50 wage pct. | hours $>0$ )

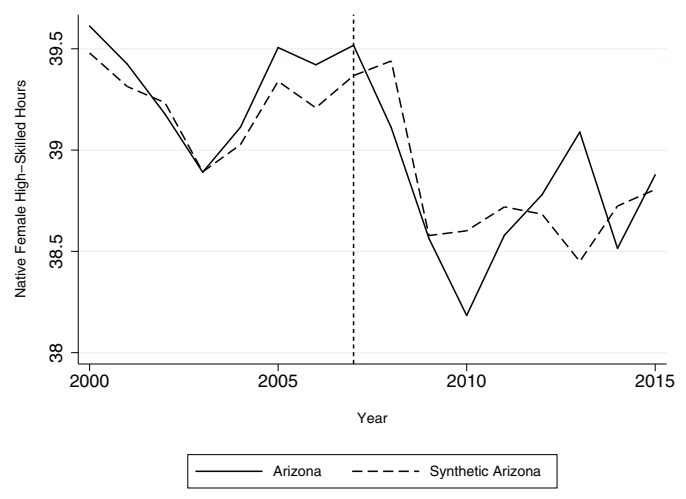

(a) 25-50 Wage pct.

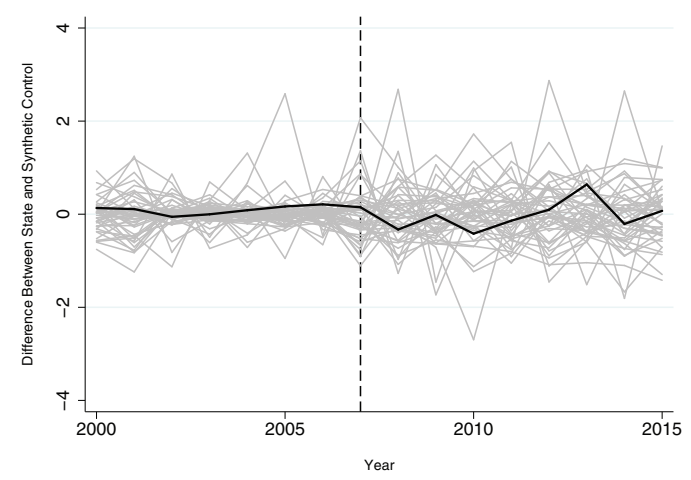

(b) Permutation Test

Figure A15 Native female weekly hours (50-75 wage pct. | hours>0)

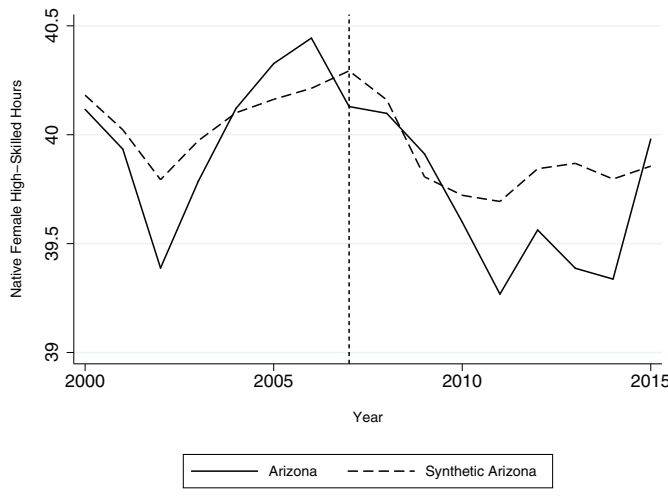

(a) 50-75 Wage pct.

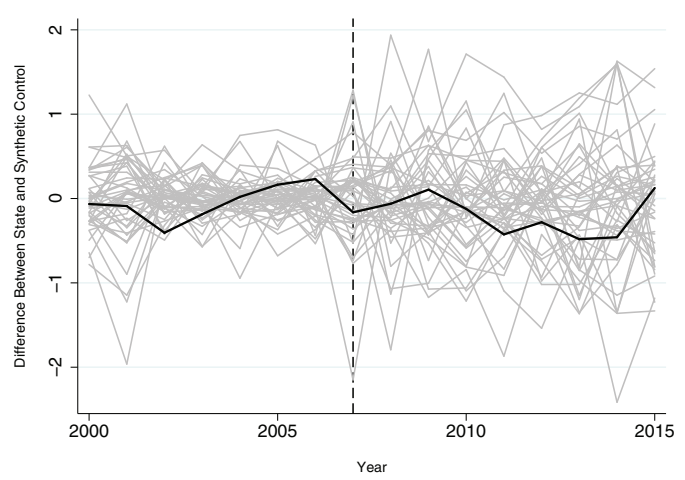

(b) Permutation Test 
Figure A16 Native female weekly hours (75-100 wage pct. | hours >0)

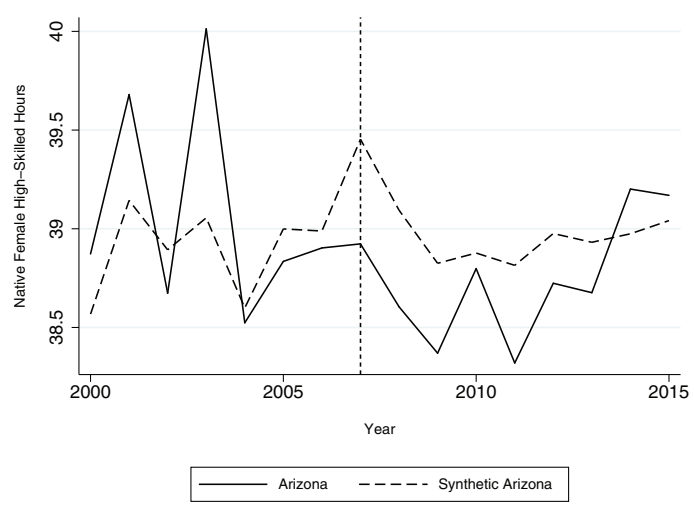

(a) 75-100 Wage pct.

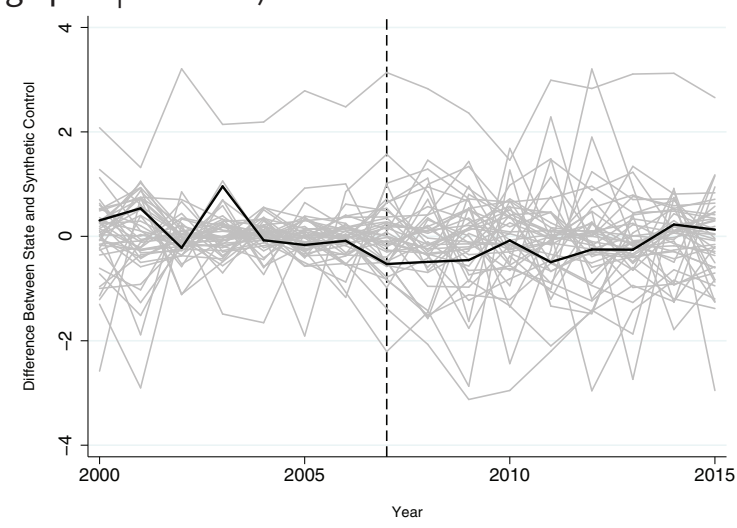

(b) Permutation Test

Figure A17 Native married women participation rate

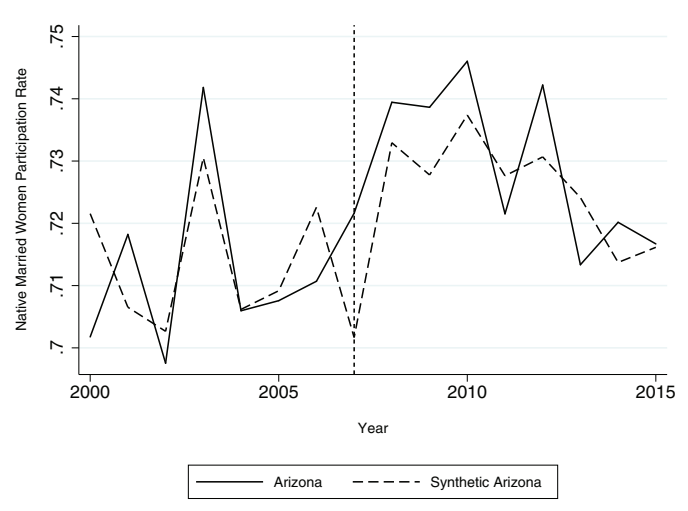

(a) Participation Rate

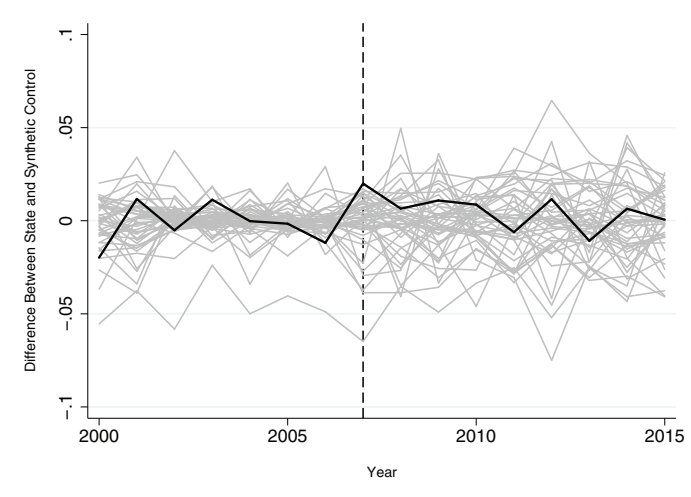

(b) Permutation Test

Figure A18 Native married women weekly hours (hours $>0$ )

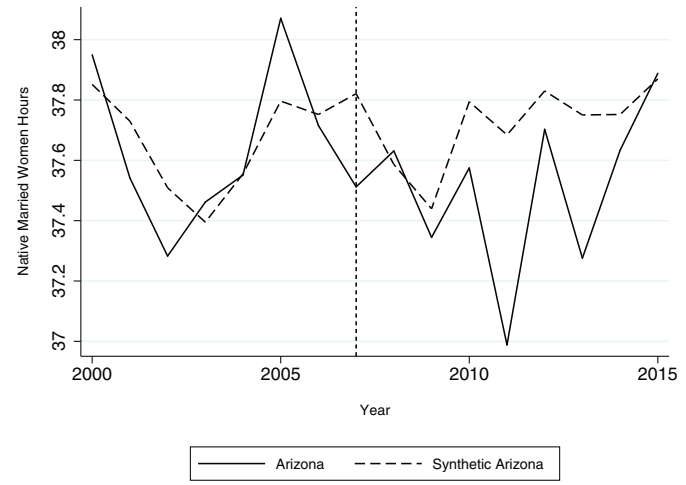

(a) Weekly Hours

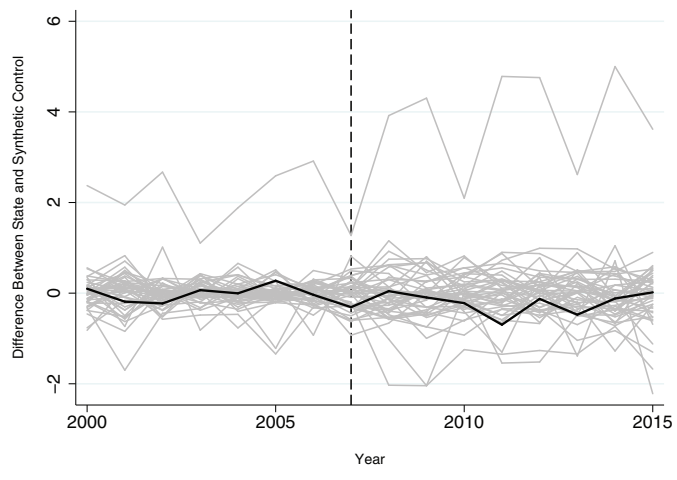

(b) Permutation Test 
Figure A19 Native high-skilled male participation rate

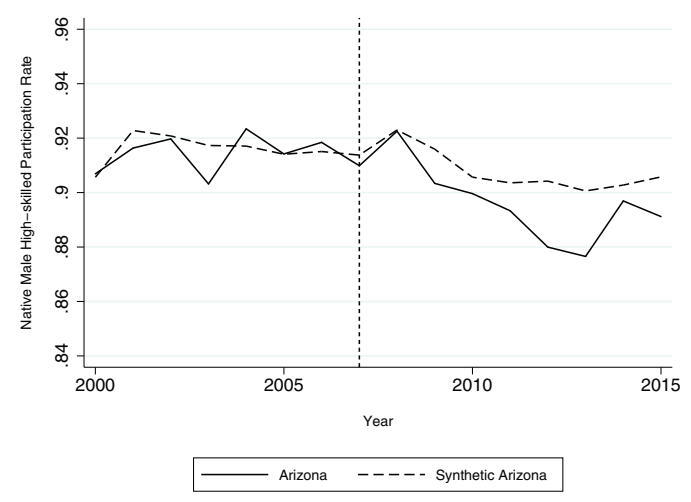

(a) Participation Rate

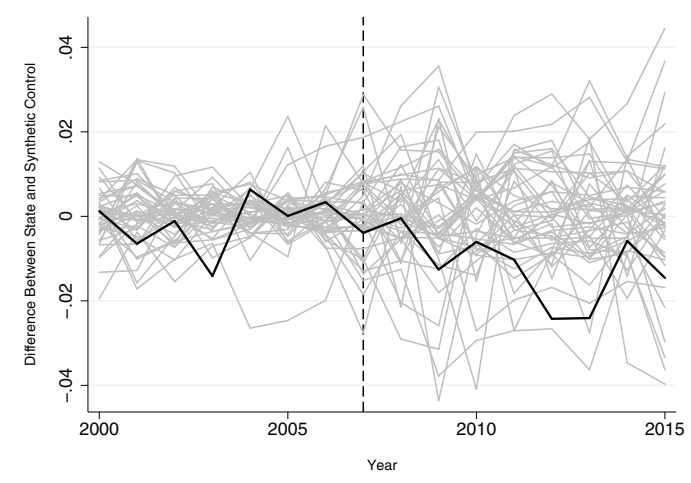

(b) Permutation Test

Figure A20 Native high-skilled male weekly hours (hours >0)

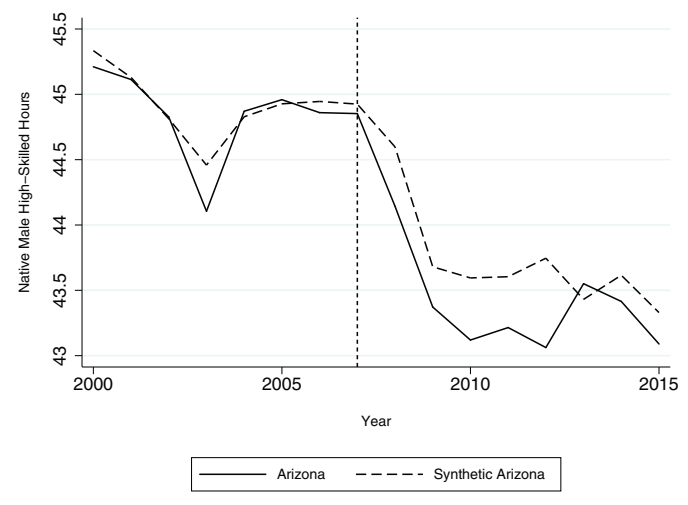

(a) Weekly Hours

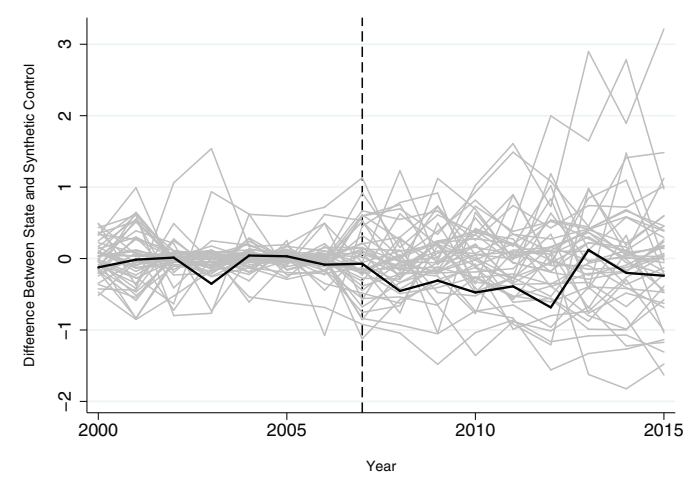

(b) Permutation Test

Figure A21 Native Low-skilled Male Participation Rate

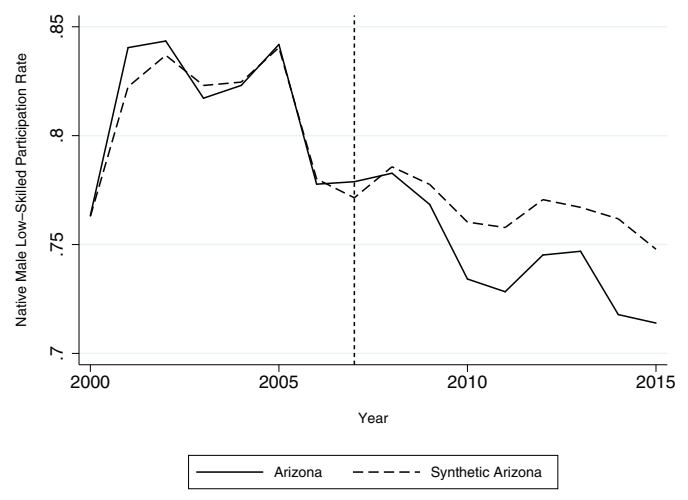

(a) Participation Rate

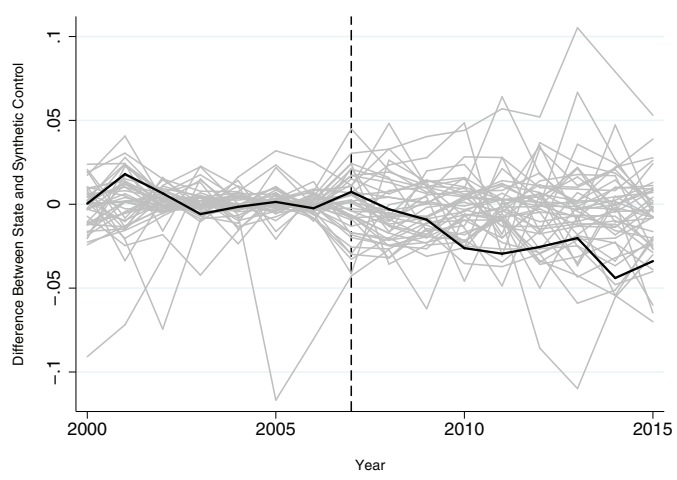

(b) Permutation Test 
Figure A22 Native low-skilled male weekly hours (hours $>0$ )

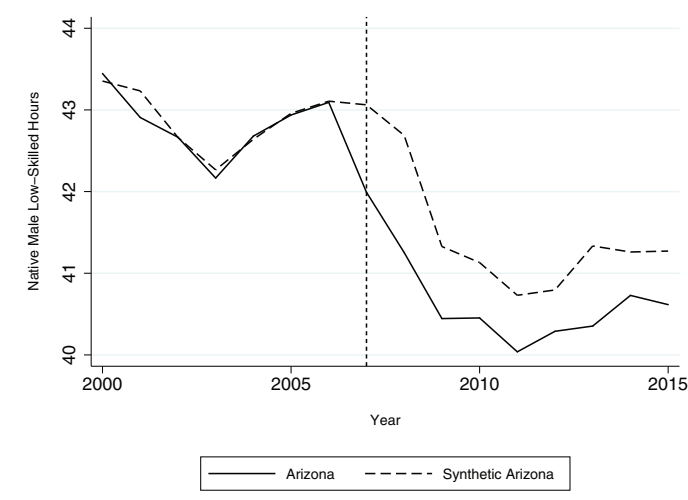

(a) Weekly Hours

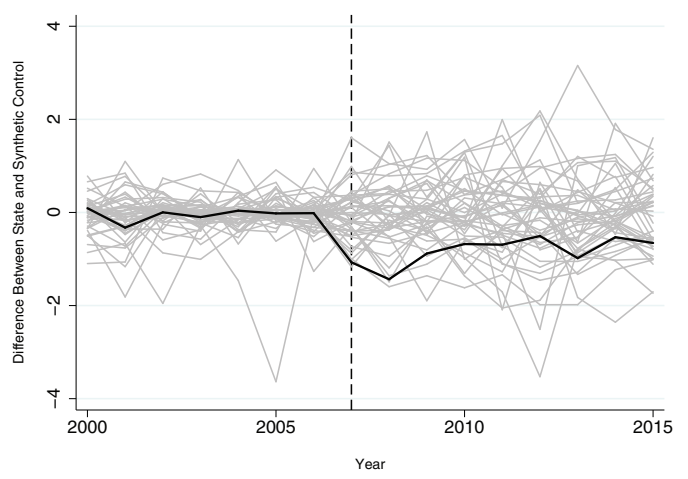

(b) Permutation Test

Figure A23 Native high-skilled male daily time spent on housework, gardening, and caring for children

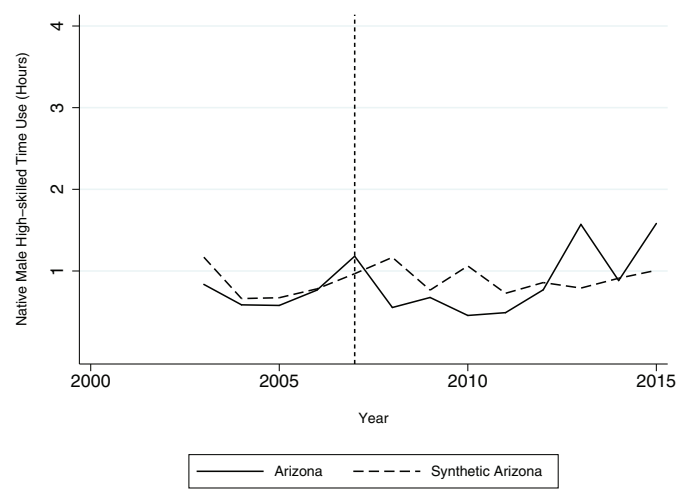

(a) High-skilled Male Daily Time Use

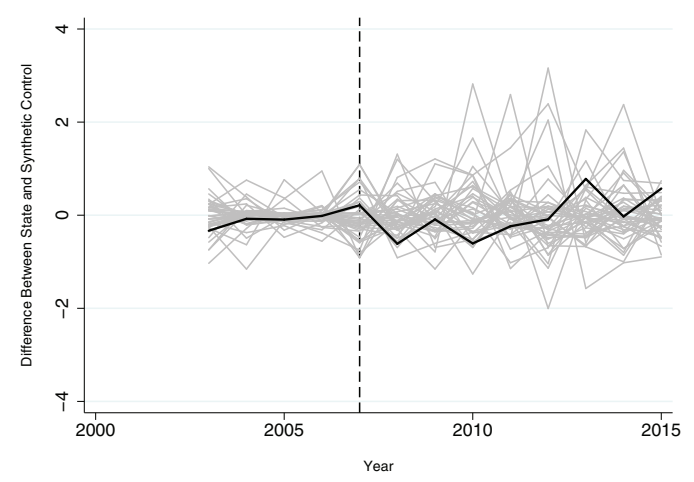

(b) Permutation Test

Figure A24 Native low-skilled male daily time spent on housework, gardening, and caring for children

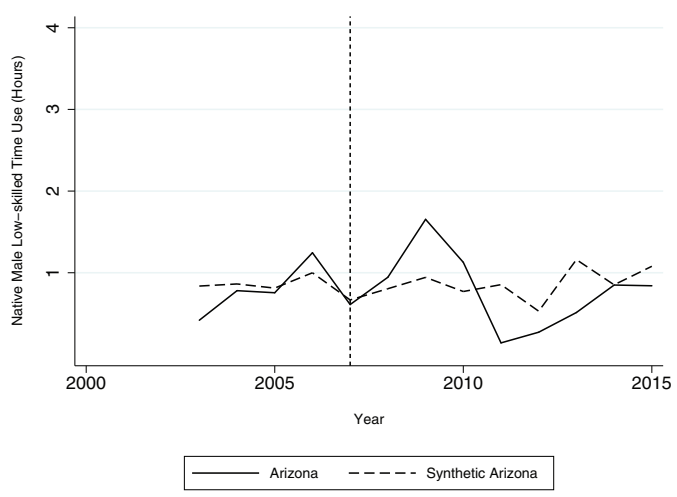

(a) Low-skilled Male Daily Time Use

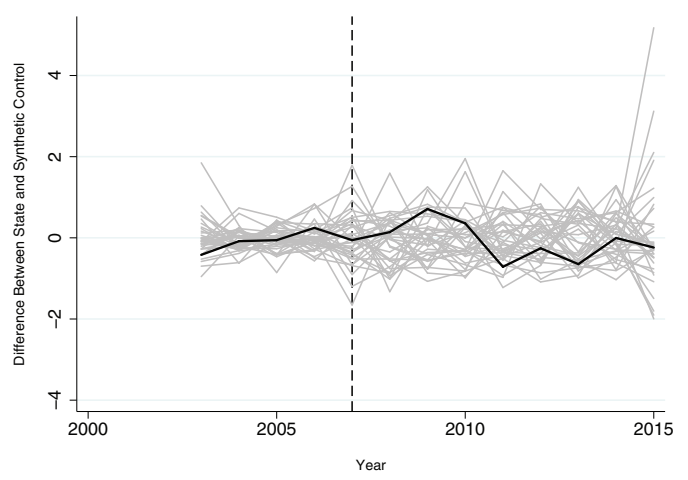

(b) Permutation Test 
Figure A25 Size of immigrant workforce (male) in household service occupations

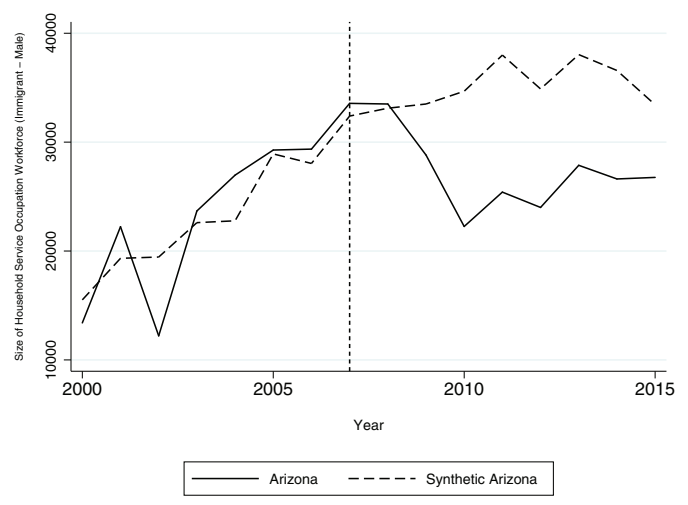

(a) Size of Workforce

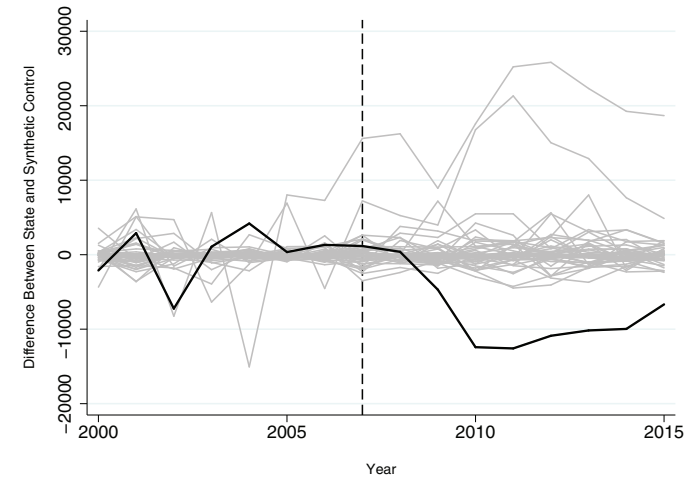

(b) Permutation Test

Figure A26 Size of immigrant workforce (female) in household service occupations

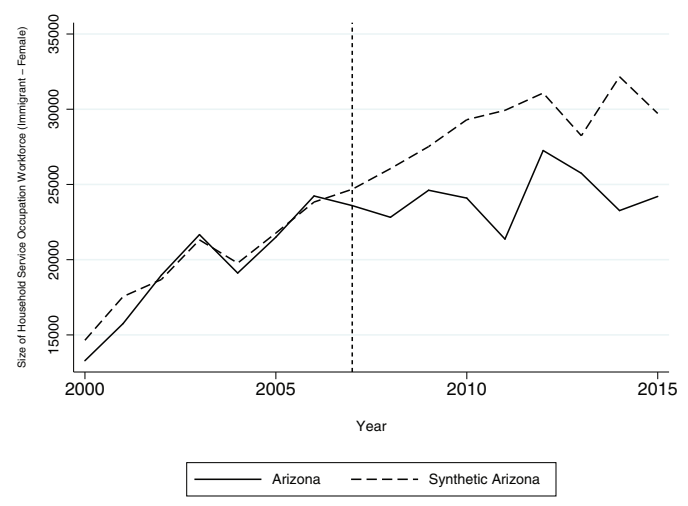

(a) Size of Natives Workforce

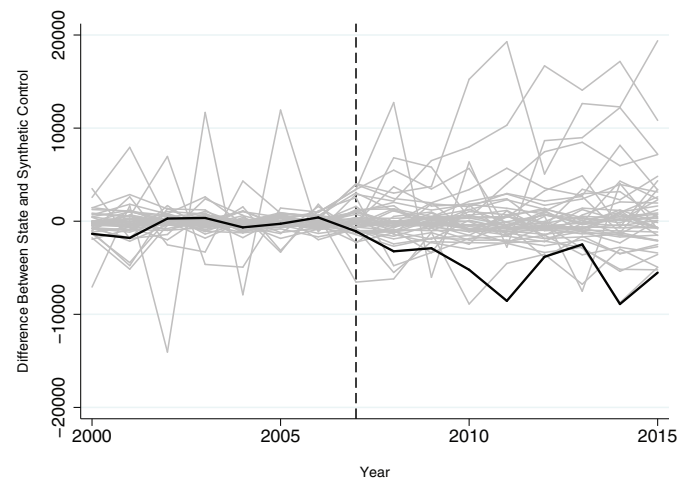

(b) Permutation Test

Figure A27 Size of native workforce (male) in household service occupations

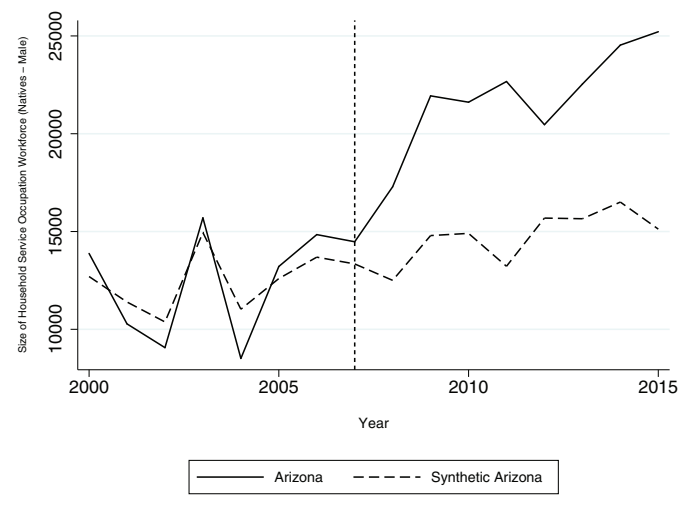

(a) Size of Workforce

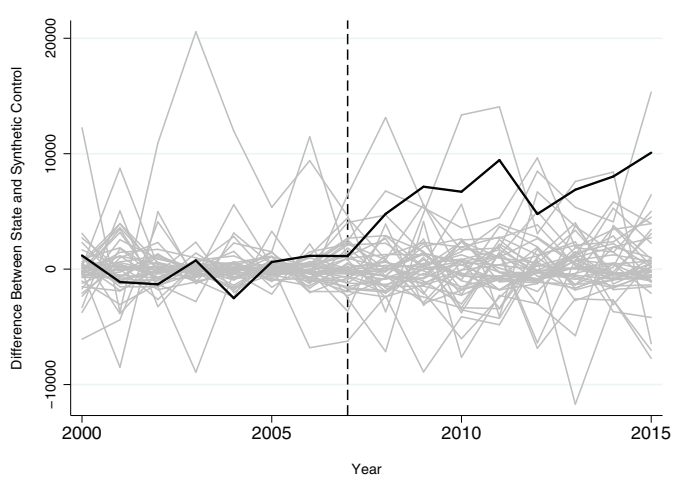

(b) Permutation Test 
Figure A28 Size of native workforce (female) in household service occupations

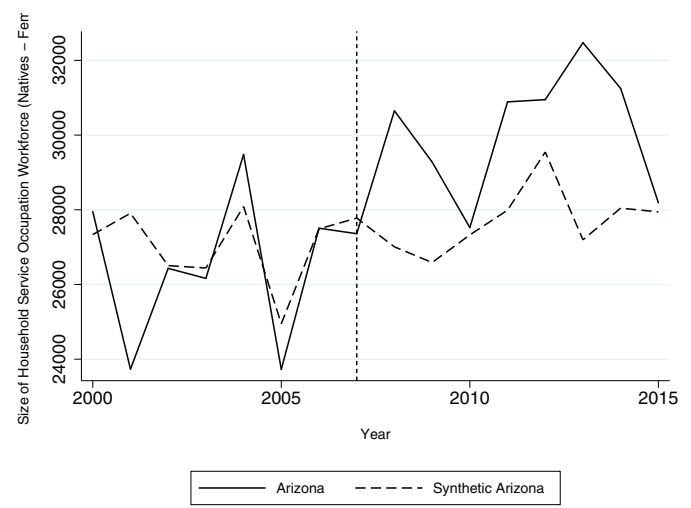

(a) Size of Natives Workforce

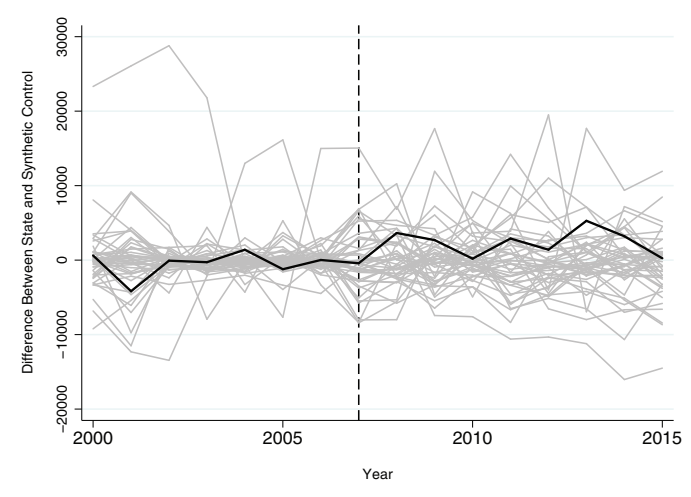

(b) Permutation Test

Figure A29 Low-skilled natives occupational income score (male)

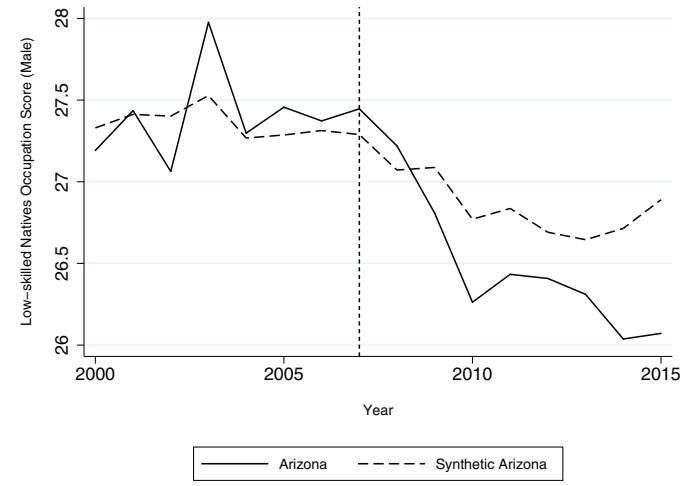

(a) Size of Workforce

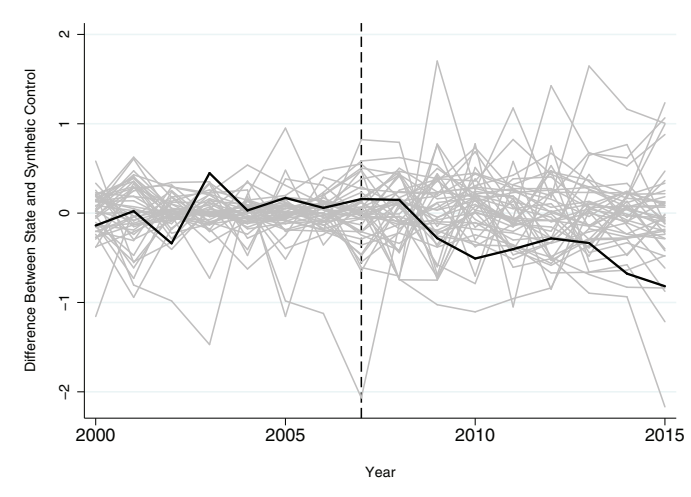

(b) Permutation Test

Figure A30 Low-skilled natives occupational income score (female)

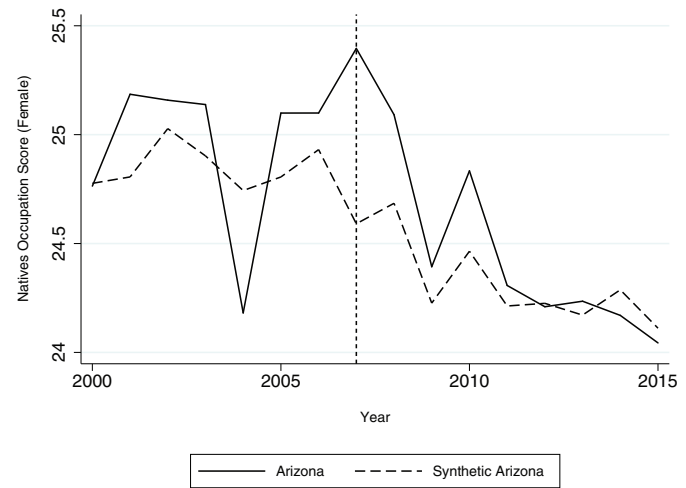

(a) Size of Natives Workforce

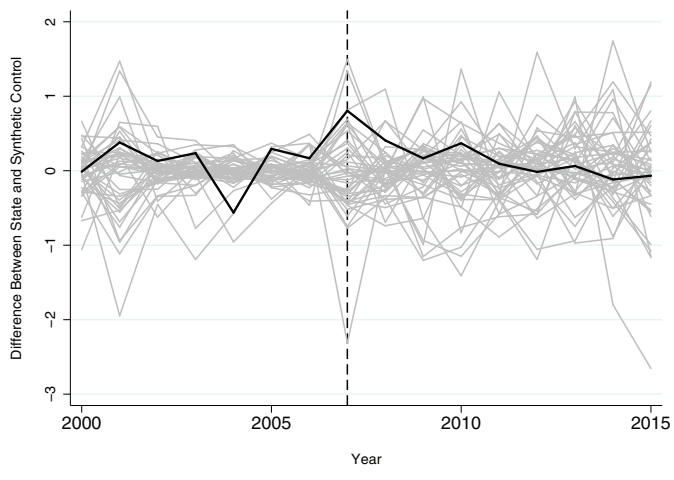

(b) Permutation Test 
Figure A31 Low-skilled natives employment rate (male)

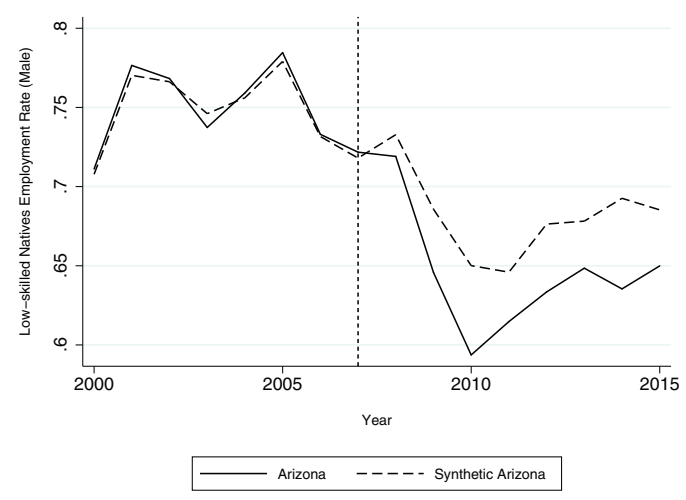

(a) Size of Workforce

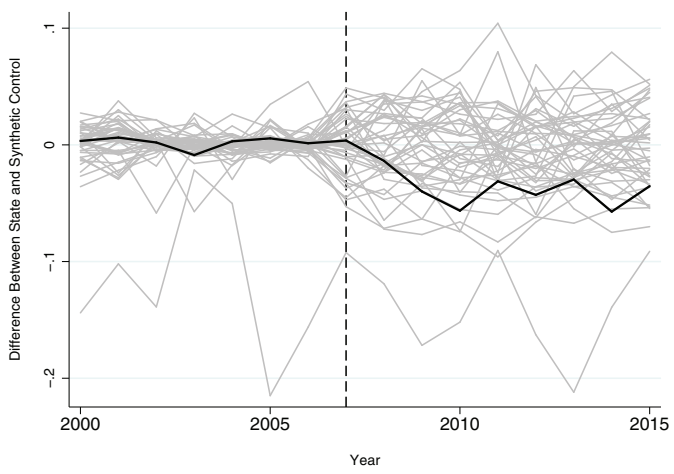

(b) Permutation Test

Figure A32 Low-skilled natives employment rate (female)

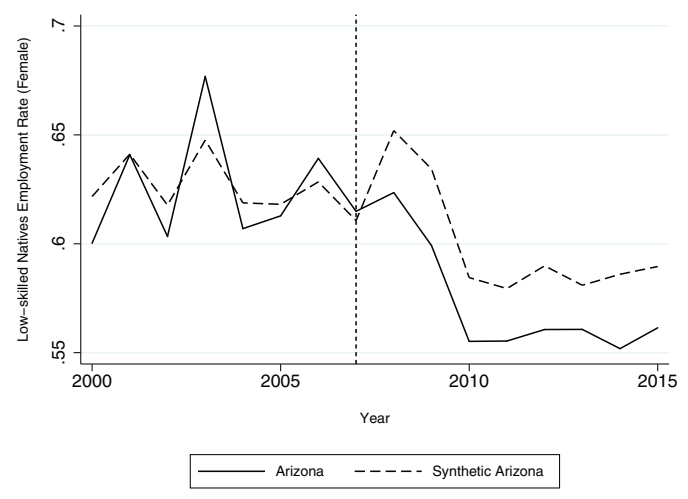

(a) Size of Natives Workforce

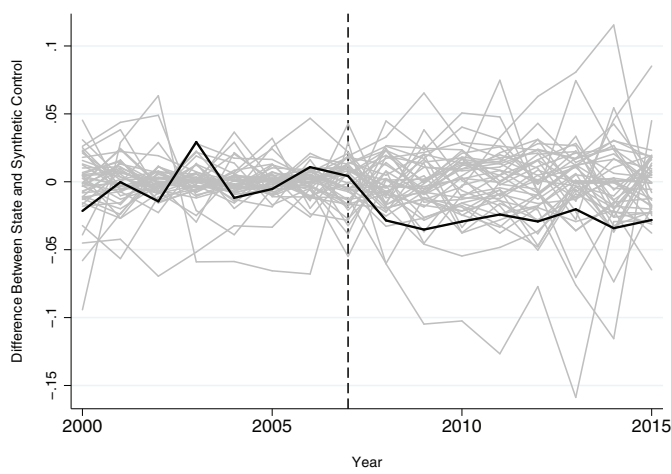

(b) Permutation Test 


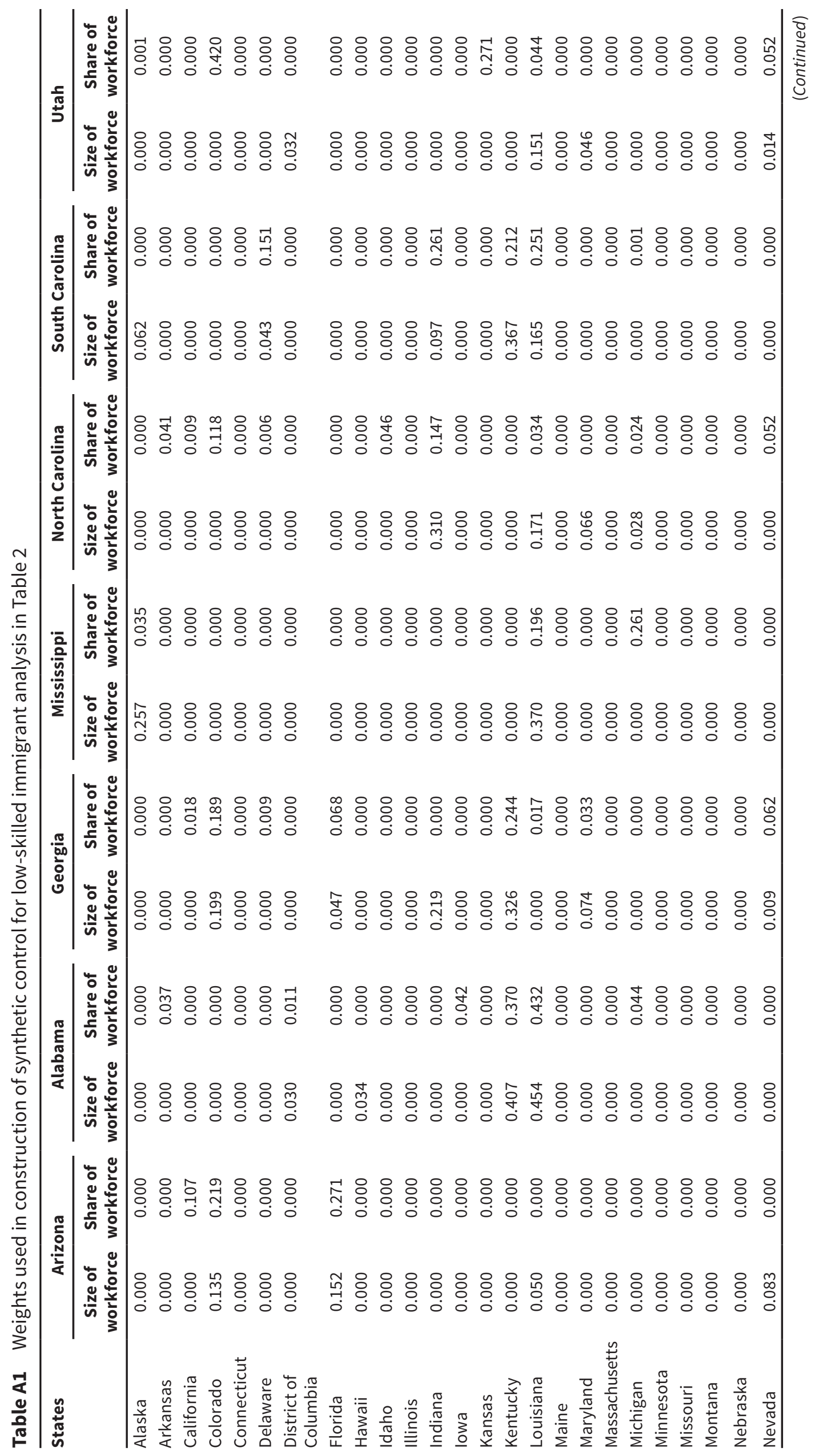




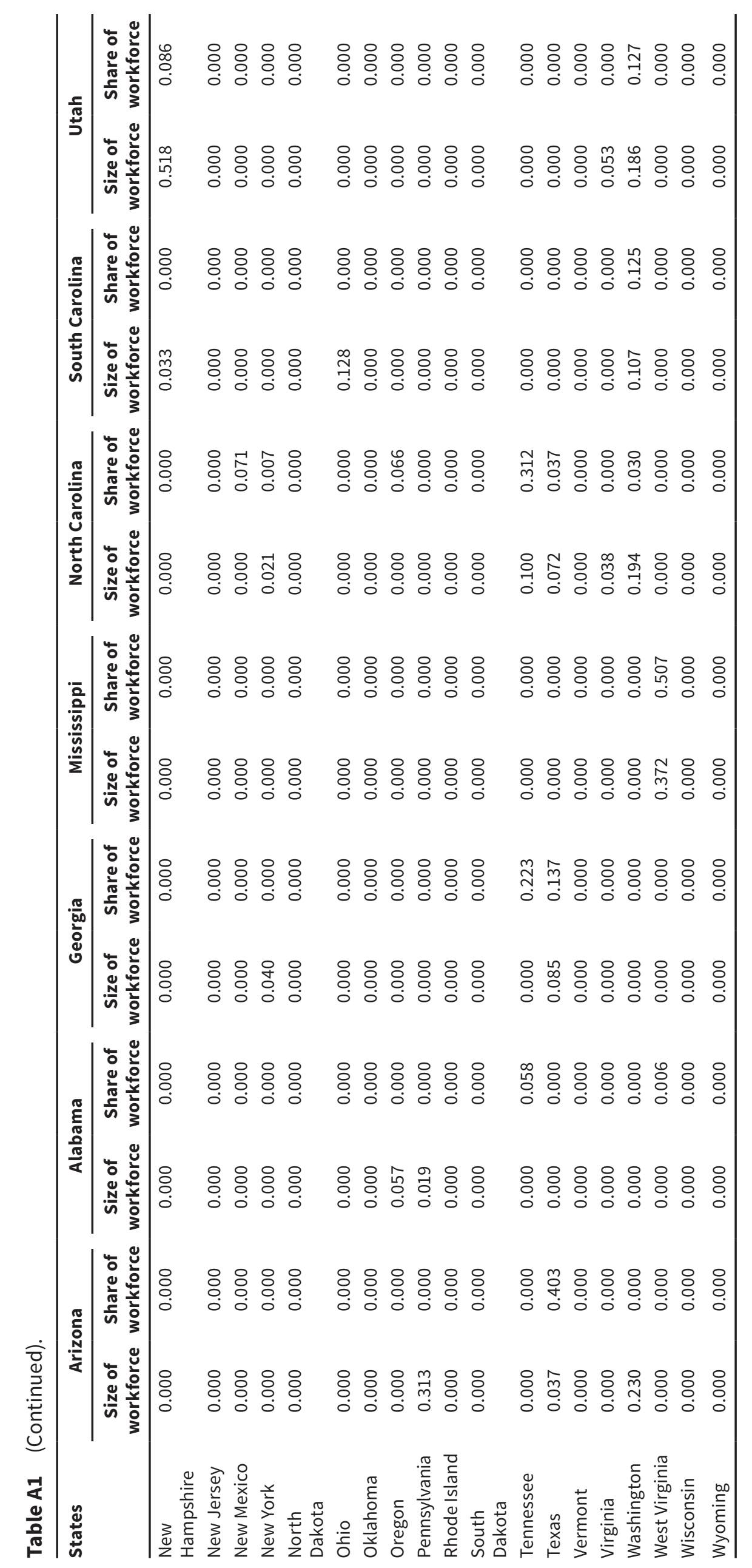


Table A2 Weights used in construction of synthetic Arizona for female labor supply analysis in Table 3

\begin{tabular}{|c|c|c|c|c|c|c|}
\hline \multirow[t]{2}{*}{ Donor states } & \multicolumn{3}{|c|}{ Labor force participation (LFP) } & \multicolumn{3}{|c|}{ Hours per week } \\
\hline & $\begin{array}{c}\text { High } \\
\text { skilled }\end{array}$ & $\begin{array}{l}\text { Low } \\
\text { skilled }\end{array}$ & Married & $\begin{array}{l}\text { High } \\
\text { skilled }\end{array}$ & $\begin{array}{l}\text { Low } \\
\text { skilled }\end{array}$ & Married \\
\hline Alaska & 0.000 & 0.089 & 0.047 & 0.000 & 0.000 & 0.000 \\
\hline Arkansas & 0.000 & 0.090 & 0.000 & 0.000 & 0.000 & 0.000 \\
\hline California & 0.079 & 0.000 & 0.000 & 0.000 & 0.000 & 0.000 \\
\hline Colorado & 0.000 & 0.383 & 0.000 & 0.285 & 0.000 & 0.176 \\
\hline Connecticut & 0.000 & 0.000 & 0.000 & 0.000 & 0.000 & 0.000 \\
\hline Delaware & 0.000 & 0.000 & 0.000 & 0.000 & 0.000 & 0.000 \\
\hline District of Columbia & 0.000 & 0.000 & 0.000 & 0.095 & 0.000 & 0.000 \\
\hline Florida & 0.037 & 0.000 & 0.000 & 0.100 & 0.042 & 0.074 \\
\hline Hawaii & 0.000 & 0.000 & 0.173 & 0.000 & 0.000 & 0.000 \\
\hline Idaho & 0.217 & 0.000 & 0.514 & 0.000 & 0.000 & 0.000 \\
\hline Illinois & 0.000 & 0.000 & 0.000 & 0.000 & 0.000 & 0.000 \\
\hline Indiana & 0.000 & 0.000 & 0.000 & 0.000 & 0.000 & 0.000 \\
\hline lowa & 0.000 & 0.000 & 0.000 & 0.000 & 0.000 & 0.000 \\
\hline Kansas & 0.000 & 0.000 & 0.000 & 0.000 & 0.000 & 0.000 \\
\hline Kentucky & 0.000 & 0.000 & 0.000 & 0.000 & 0.000 & 0.000 \\
\hline Louisiana & 0.000 & 0.000 & 0.000 & 0.000 & 0.000 & 0.000 \\
\hline Maine & 0.000 & 0.000 & 0.000 & 0.153 & 0.156 & 0.151 \\
\hline Maryland & 0.000 & 0.000 & 0.000 & 0.000 & 0.000 & 0.075 \\
\hline Massachusetts & 0.000 & 0.000 & 0.000 & 0.000 & 0.000 & 0.000 \\
\hline Michigan & 0.000 & 0.000 & 0.000 & 0.000 & 0.000 & 0.000 \\
\hline Minnesota & 0.000 & 0.000 & 0.000 & 0.000 & 0.000 & 0.000 \\
\hline Missouri & 0.000 & 0.000 & 0.000 & 0.000 & 0.000 & 0.000 \\
\hline Montana & 0.000 & 0.106 & 0.000 & 0.000 & 0.000 & 0.000 \\
\hline Nebraska & 0.000 & 0.000 & 0.000 & 0.000 & 0.000 & 0.000 \\
\hline Nevada & 0.124 & 0.028 & 0.072 & 0.192 & 0.127 & 0.160 \\
\hline New Hampshire & 0.000 & 0.000 & 0.000 & 0.015 & 0.000 & 0.000 \\
\hline New Jersey & 0.000 & 0.000 & 0.000 & 0.000 & 0.000 & 0.000 \\
\hline New Mexico & 0.092 & 0.000 & 0.000 & 0.000 & 0.060 & 0.000 \\
\hline New York & 0.000 & 0.000 & 0.000 & 0.000 & 0.000 & 0.000 \\
\hline North Dakota & 0.000 & 0.000 & 0.000 & 0.000 & 0.000 & 0.000 \\
\hline Ohio & 0.000 & 0.000 & 0.000 & 0.000 & 0.000 & 0.000 \\
\hline Oklahoma & 0.252 & 0.000 & 0.000 & 0.000 & 0.000 & 0.000 \\
\hline Oregon & 0.000 & 0.000 & 0.025 & 0.000 & 0.000 & 0.000 \\
\hline Pennsylvania & 0.000 & 0.000 & 0.000 & 0.000 & 0.000 & 0.000 \\
\hline Rhode Island & 0.000 & 0.000 & 0.000 & 0.000 & 0.000 & 0.000 \\
\hline South Dakota & 0.000 & 0.000 & 0.000 & 0.000 & 0.206 & 0.000 \\
\hline Tennessee & 0.000 & 0.000 & 0.000 & 0.000 & 0.000 & 0.000 \\
\hline Texas & 0.199 & 0.000 & 0.003 & 0.150 & 0.409 & 0.364 \\
\hline Vermont & 0.000 & 0.000 & 0.000 & 0.011 & 0.000 & 0.000 \\
\hline Virginia & 0.000 & 0.000 & 0.000 & 0.000 & 0.000 & 0.000 \\
\hline Washington & 0.000 & 0.075 & 0.000 & 0.000 & 0.000 & 0.000 \\
\hline West Virginia & 0.000 & 0.230 & 0.167 & 0.000 & 0.000 & 0.000 \\
\hline Wisconsin & 0.000 & 0.000 & 0.000 & 0.000 & 0.000 & 0.000 \\
\hline Wyoming & 0.000 & 0.000 & 0.000 & 0.000 & 0.000 & 0.000 \\
\hline
\end{tabular}


Table A3 Weights used in construction of synthetic Arizona for male labor supply analysis in Table 3

\begin{tabular}{|c|c|c|c|c|}
\hline \multirow[t]{2}{*}{ Donor states } & \multicolumn{2}{|c|}{ Labor force participation (LFP) } & \multicolumn{2}{|c|}{ Hours per week } \\
\hline & High skilled & Low skilled & High skilled & Low skilled \\
\hline Alaska & 0.000 & 0.000 & 0.000 & 0.000 \\
\hline Arkansas & 0.155 & 0.000 & 0.000 & 0.000 \\
\hline California & 0.224 & 0.463 & 0.129 & 0.071 \\
\hline Colorado & 0.000 & 0.000 & 0.128 & 0.466 \\
\hline Connecticut & 0.000 & 0.000 & 0.000 & 0.000 \\
\hline Delaware & 0.000 & 0.000 & 0.000 & 0.000 \\
\hline District of Columbia & 0.000 & 0.016 & 0.000 & 0.022 \\
\hline Florida & 0.124 & 0.000 & 0.220 & 0.011 \\
\hline Hawaii & 0.073 & 0.000 & 0.000 & 0.000 \\
\hline Idaho & 0.000 & 0.000 & 0.000 & 0.034 \\
\hline Illinois & 0.000 & 0.000 & 0.000 & 0.000 \\
\hline Indiana & 0.000 & 0.000 & 0.000 & 0.000 \\
\hline lowa & 0.000 & 0.000 & 0.000 & 0.000 \\
\hline Kansas & 0.000 & 0.000 & 0.000 & 0.000 \\
\hline Kentucky & 0.000 & 0.000 & 0.000 & 0.000 \\
\hline Louisiana & 0.000 & 0.046 & 0.000 & 0.000 \\
\hline Maine & 0.000 & 0.000 & 0.000 & 0.000 \\
\hline Maryland & 0.000 & 0.000 & 0.000 & 0.000 \\
\hline Massachusetts & 0.000 & 0.000 & 0.000 & 0.000 \\
\hline Michigan & 0.000 & 0.000 & 0.000 & 0.000 \\
\hline Minnesota & 0.000 & 0.000 & 0.000 & 0.000 \\
\hline Missouri & 0.000 & 0.000 & 0.000 & 0.000 \\
\hline Montana & 0.000 & 0.233 & 0.193 & 0.000 \\
\hline Nebraska & 0.000 & 0.000 & 0.000 & 0.000 \\
\hline Nevada & 0.115 & 0.000 & 0.160 & 0.315 \\
\hline New Hampshire & 0.000 & 0.000 & 0.000 & 0.000 \\
\hline New Jersey & 0.000 & 0.000 & 0.000 & 0.000 \\
\hline New Mexico & 0.122 & 0.000 & 0.000 & 0.000 \\
\hline New York & 0.000 & 0.000 & 0.000 & 0.000 \\
\hline North Dakota & 0.000 & 0.000 & 0.000 & 0.000 \\
\hline Ohio & 0.000 & 0.000 & 0.000 & 0.000 \\
\hline Oklahoma & 0.000 & 0.000 & 0.000 & 0.000 \\
\hline Oregon & 0.000 & 0.000 & 0.000 & 0.020 \\
\hline Pennsylvania & 0.000 & 0.000 & 0.000 & 0.000 \\
\hline Rhode Island & 0.000 & 0.037 & 0.000 & 0.000 \\
\hline South Dakota & 0.000 & 0.000 & 0.000 & 0.000 \\
\hline Tennessee & 0.084 & 0.000 & 0.111 & 0.000 \\
\hline Texas & 0.000 & 0.000 & 0.054 & 0.000 \\
\hline Vermont & 0.000 & 0.000 & 0.000 & 0.000 \\
\hline Virginia & 0.000 & 0.070 & 0.000 & 0.000 \\
\hline Washington & 0.000 & 0.000 & 0.006 & 0.061 \\
\hline West Virginia & 0.000 & 0.135 & 0.000 & 0.000 \\
\hline Wisconsin & 0.000 & 0.000 & 0.000 & 0.000 \\
\hline Wyoming & 0.103 & 0.000 & 0.000 & 0.000 \\
\hline
\end{tabular}


Table A4 Weights used in construction of synthetic Arizona for female labor supply analysis in Table 3

\begin{tabular}{|c|c|c|c|c|}
\hline Donor states & $0-25$ pct. & 25-50 pct. & 50-75 pct. & 75-100 pct. \\
\hline Alaska & 0.000 & 0.000 & 0.000 & 0.000 \\
\hline Arkansas & 0.000 & 0.000 & 0.000 & 0.000 \\
\hline California & 0.000 & 0.007 & 0.000 & 0.000 \\
\hline Colorado & 0.064 & 0.169 & 0.198 & 0.170 \\
\hline Connecticut & 0.000 & 0.000 & 0.000 & 0.000 \\
\hline Delaware & 0.000 & 0.087 & 0.000 & 0.000 \\
\hline District of Columbia & 0.014 & 0.010 & 0.000 & 0.015 \\
\hline Florida & 0.000 & 0.391 & 0.163 & 0.406 \\
\hline Hawaii & 0.000 & 0.001 & 0.000 & 0.000 \\
\hline Idaho & 0.000 & 0.019 & 0.000 & 0.000 \\
\hline Illinois & 0.000 & 0.000 & 0.000 & 0.000 \\
\hline Indiana & 0.000 & 0.000 & 0.000 & 0.054 \\
\hline lowa & 0.000 & 0.000 & 0.000 & 0.000 \\
\hline Kansas & 0.000 & 0.000 & 0.000 & 0.000 \\
\hline Kentucky & 0.000 & 0.000 & 0.000 & 0.000 \\
\hline Louisiana & 0.000 & 0.000 & 0.000 & 0.000 \\
\hline Maine & 0.000 & 0.000 & 0.000 & 0.000 \\
\hline Maryland & 0.000 & 0.000 & 0.000 & 0.000 \\
\hline Massachusetts & 0.000 & 0.000 & 0.000 & 0.000 \\
\hline Michigan & 0.000 & 0.000 & 0.000 & 0.000 \\
\hline Minnesota & 0.000 & 0.000 & 0.000 & 0.000 \\
\hline Missouri & 0.000 & 0.000 & 0.000 & 0.000 \\
\hline Montana & 0.000 & 0.000 & 0.000 & 0.000 \\
\hline Nebraska & 0.240 & 0.000 & 0.000 & 0.000 \\
\hline Nevada & 0.118 & 0.074 & 0.203 & 0.095 \\
\hline New Hampshire & 0.000 & 0.000 & 0.000 & 0.000 \\
\hline New Jersey & 0.000 & 0.000 & 0.000 & 0.000 \\
\hline New Mexico & 0.230 & 0.000 & 0.000 & 0.000 \\
\hline New York & 0.000 & 0.000 & 0.124 & 0.000 \\
\hline North Dakota & 0.000 & 0.000 & 0.000 & 0.000 \\
\hline Ohio & 0.000 & 0.000 & 0.000 & 0.000 \\
\hline Oklahoma & 0.000 & 0.000 & 0.000 & 0.000 \\
\hline Oregon & 0.000 & 0.000 & 0.000 & 0.000 \\
\hline Pennsylvania & 0.000 & 0.000 & 0.000 & 0.000 \\
\hline Rhode Island & 0.000 & 0.000 & 0.000 & 0.000 \\
\hline South Dakota & 0.000 & 0.000 & 0.000 & 0.000 \\
\hline Tennessee & 0.000 & 0.000 & 0.000 & 0.000 \\
\hline Texas & 0.336 & 0.240 & 0.313 & 0.095 \\
\hline Vermont & 0.000 & 0.000 & 0.000 & 0.000 \\
\hline Virginia & 0.000 & 0.000 & 0.000 & 0.135 \\
\hline Washington & 0.000 & 0.000 & 0.000 & 0.000 \\
\hline West Virginia & 0.000 & 0.000 & 0.000 & 0.031 \\
\hline Wisconsin & 0.000 & 0.000 & 0.000 & 0.000 \\
\hline Wyoming & 0.000 & 0.000 & 0.000 & 0.000 \\
\hline
\end{tabular}


Table A5 Weights used in construction of synthetic Arizona for time-use analysis in Table 4

\begin{tabular}{|c|c|c|c|c|c|c|c|}
\hline \multicolumn{2}{|c|}{ High-skilled female } & \multicolumn{2}{|c|}{ Low-skilled female } & \multicolumn{2}{|c|}{ High-skilled male } & \multicolumn{2}{|c|}{ Low-skilled male } \\
\hline Donor states & Weight & Donor states & Weight & Donor states & Weight & Donor states & Weight \\
\hline Alaska & 0.010 & Arkansas & 0.000 & Arkansas & 0.000 & Arkansas & 0.002 \\
\hline Arkansas & 0.000 & California & 0.000 & California & 0.000 & California & 0.000 \\
\hline California & 0.000 & Colorado & 0.000 & Colorado & 0.180 & Colorado & 0.450 \\
\hline Colorado & 0.275 & Connecticut & 0.000 & Connecticut & 0.000 & Connecticut & 0.000 \\
\hline Connecticut & 0.000 & Florida & 0.209 & Delaware & 0.000 & Florida & 0.189 \\
\hline Delaware & 0.145 & Hawaii & 0.043 & $\begin{array}{l}\text { District of } \\
\text { Columbia }\end{array}$ & 0.000 & Idaho & 0.000 \\
\hline $\begin{array}{l}\text { District of } \\
\text { Columbia }\end{array}$ & 0.000 & Idaho & 0.073 & Florida & 0.064 & Illinois & 0.000 \\
\hline Florida & 0.248 & Illinois & 0.000 & Hawaii & 0.022 & Indiana & 0.000 \\
\hline Hawaii & 0.000 & Indiana & 0.000 & Idaho & 0.000 & lowa & 0.000 \\
\hline Idaho & 0.149 & lowa & 0.000 & Illinois & 0.000 & Kansas & 0.000 \\
\hline Illinois & 0.000 & Kansas & 0.000 & Indiana & 0.000 & Kentucky & 0.015 \\
\hline Indiana & 0.000 & Kentucky & 0.000 & lowa & 0.000 & Louisiana & 0.000 \\
\hline lowa & 0.000 & Louisiana & 0.000 & Kansas & 0.000 & Maine & 0.000 \\
\hline Kansas & 0.000 & Maryland & 0.051 & Kentucky & 0.000 & Maryland & 0.000 \\
\hline Kentucky & 0.000 & Massachusetts & 0.000 & Louisiana & 0.188 & Massachusetts & 0.000 \\
\hline Louisiana & 0.046 & Michigan & 0.000 & Maine & 0.000 & Michigan & 0.000 \\
\hline Maine & 0.000 & Minnesota & 0.000 & Maryland & 0.000 & Minnesota & 0.000 \\
\hline Maryland & 0.000 & Missouri & 0.000 & Massachusetts & 0.000 & Missouri & 0.000 \\
\hline Massachusetts & 0.000 & Montana & 0.000 & Michigan & 0.000 & Montana & 0.000 \\
\hline Michigan & 0.000 & Nebraska & 0.000 & Minnesota & 0.000 & Nebraska & 0.000 \\
\hline Minnesota & 0.000 & Nevada & 0.127 & Missouri & 0.000 & Nevada & 0.113 \\
\hline Missouri & 0.000 & $\begin{array}{l}\text { New Hamp- } \\
\text { shire }\end{array}$ & 0.000 & Montana & 0.000 & $\begin{array}{l}\text { New } \\
\text { Hampshire }\end{array}$ & 0.000 \\
\hline Montana & 0.000 & New Jersey & 0.000 & Nebraska & 0.000 & New Jersey & 0.000 \\
\hline Nebraska & 0.000 & New Mexico & 0.000 & Nevada & 0.143 & New Mexico & 0.000 \\
\hline Nevada & 0.126 & New York & 0.000 & New Hampshire & 0.000 & New York & 0.000 \\
\hline New Hampshire & 0.000 & Ohio & 0.000 & New Jersey & 0.000 & North Dakota & 0.000 \\
\hline New Jersey & 0.000 & Oklahoma & 0.000 & New Mexico & 0.000 & Ohio & 0.000 \\
\hline New Mexico & 0.000 & Oregon & 0.000 & New York & 0.000 & Oklahoma & 0.000 \\
\hline New York & 0.000 & Pennsylvania & 0.000 & North Dakota & 0.000 & Oregon & 0.002 \\
\hline North Dakota & 0.000 & Rhode Island & 0.000 & Ohio & 0.000 & Pennsylvania & 0.000 \\
\hline Ohio & 0.000 & South Dakota & 0.104 & Oklahoma & 0.000 & Tennessee & 0.000 \\
\hline Oklahoma & 0.000 & Tennessee & 0.000 & Oregon & 0.000 & Texas & 0.166 \\
\hline Oregon & 0.000 & Texas & 0.392 & Pennsylvania & 0.000 & Virginia & 0.063 \\
\hline Pennsylvania & 0.000 & Virginia & 0.000 & Rhode Island & 0.000 & Washington & 0.000 \\
\hline Rhode Island & 0.000 & Washington & 0.001 & South Dakota & 0.089 & West Virginia & 0.000 \\
\hline South Dakota & 0.000 & West Virginia & 0.000 & Tennessee & 0.000 & Wisconsin & 0.000 \\
\hline Tennessee & 0.000 & Wisconsin & 0.000 & Texas & 0.205 & & \\
\hline Texas & 0.000 & & & Vermont & 0.000 & & \\
\hline Vermont & 0.000 & & & Virginia & 0.109 & & \\
\hline Virginia & 0.000 & & & Washington & 0.000 & & \\
\hline Washington & 0.000 & & & West Virginia & 0.000 & & \\
\hline West Virginia & 0.000 & & & Wisconsin & 0.000 & & \\
\hline Wisconsin & 0.000 & & & & & & \\
\hline Wyoming & 0.000 & & & & & & \\
\hline
\end{tabular}


Table A6 Weights used in construction of synthetic Arizona for household service sector analysis in Table 5

\begin{tabular}{|c|c|c|c|c|c|c|c|c|}
\hline Donor states & $\begin{array}{c}\text { Hourly } \\
\text { wage }\end{array}$ & $\begin{array}{l}\text { Native } \\
\text { supply }\end{array}$ & $\begin{array}{c}\text { Native } \\
\text { male }\end{array}$ & $\begin{array}{l}\text { Native } \\
\text { female }\end{array}$ & $\begin{array}{l}\text { Immigrant } \\
\text { supply }\end{array}$ & $\begin{array}{l}\text { Immigrant } \\
\text { male }\end{array}$ & $\begin{array}{l}\text { Immigrant } \\
\text { female }\end{array}$ & $\begin{array}{l}\text { Overall } \\
\text { supply }\end{array}$ \\
\hline Alaska & 0.000 & 0.000 & 0.000 & 0.000 & 0.000 & 0.000 & 0.000 & 0.000 \\
\hline Arkansas & 0.000 & 0.000 & 0.000 & 0.000 & 0.000 & 0.000 & 0.000 & 0.000 \\
\hline California & 0.000 & 0.064 & 0.000 & 0.056 & 0.000 & 0.015 & 0.000 & 0.000 \\
\hline Colorado & 0.102 & 0.386 & 0.000 & 0.000 & 0.000 & 0.000 & 0.057 & 0.411 \\
\hline Connecticut & 0.000 & 0.000 & 0.000 & 0.000 & 0.000 & 0.000 & 0.000 & 0.000 \\
\hline Delaware & 0.000 & 0.000 & 0.000 & 0.000 & 0.000 & 0.000 & 0.000 & 0.000 \\
\hline $\begin{array}{l}\text { District of } \\
\text { Columbia }\end{array}$ & 0.000 & 0.000 & 0.000 & 0.001 & 0.000 & 0.000 & 0.000 & 0.000 \\
\hline Florida & 0.282 & 0.000 & 0.000 & 0.000 & 0.000 & 0.000 & 0.020 & 0.000 \\
\hline Hawaii & 0.000 & 0.031 & 0.000 & 0.030 & 0.000 & 0.000 & 0.000 & 0.000 \\
\hline Idaho & 0.044 & 0.000 & 0.000 & 0.000 & 0.110 & 0.000 & 0.000 & 0.011 \\
\hline Illinois & 0.000 & 0.000 & 0.000 & 0.000 & 0.042 & 0.058 & 0.000 & 0.000 \\
\hline Indiana & 0.000 & 0.000 & 0.000 & 0.000 & 0.000 & 0.000 & 0.000 & 0.000 \\
\hline lowa & 0.000 & 0.000 & 0.000 & 0.000 & 0.000 & 0.000 & 0.000 & 0.000 \\
\hline Kansas & 0.000 & 0.000 & 0.000 & 0.174 & 0.000 & 0.000 & 0.000 & 0.000 \\
\hline Kentucky & 0.032 & 0.000 & 0.000 & 0.000 & 0.000 & 0.000 & 0.000 & 0.000 \\
\hline Louisiana & 0.000 & 0.000 & 0.000 & 0.000 & 0.000 & 0.000 & 0.000 & 0.000 \\
\hline Maine & 0.000 & 0.000 & 0.000 & 0.000 & 0.000 & 0.000 & 0.000 & 0.000 \\
\hline Maryland & 0.038 & 0.000 & 0.000 & 0.000 & 0.000 & 0.000 & 0.000 & 0.000 \\
\hline Massachusetts & 0.000 & 0.000 & 0.000 & 0.084 & 0.000 & 0.000 & 0.000 & 0.000 \\
\hline Michigan & 0.000 & 0.000 & 0.000 & 0.000 & 0.210 & 0.000 & 0.000 & 0.000 \\
\hline Minnesota & 0.000 & 0.000 & 0.025 & 0.000 & 0.000 & 0.000 & 0.000 & 0.000 \\
\hline Missouri & 0.000 & 0.000 & 0.000 & 0.000 & 0.000 & 0.000 & 0.000 & 0.000 \\
\hline Montana & 0.099 & 0.000 & 0.000 & 0.059 & 0.000 & 0.000 & 0.000 & 0.000 \\
\hline Nebraska & 0.000 & 0.000 & 0.000 & 0.000 & 0.000 & 0.000 & 0.000 & 0.000 \\
\hline Nevada & 0.000 & 0.230 & 0.377 & 0.433 & 0.000 & 0.000 & 0.137 & 0.170 \\
\hline New Hampshire & 0.000 & 0.019 & 0.000 & 0.000 & 0.000 & 0.000 & 0.000 & 0.000 \\
\hline New Jersey & 0.000 & 0.000 & 0.092 & 0.000 & 0.443 & 0.000 & 0.000 & 0.208 \\
\hline New Mexico & 0.000 & 0.231 & 0.000 & 0.000 & 0.000 & 0.000 & 0.336 & 0.074 \\
\hline New York & 0.000 & 0.000 & 0.000 & 0.000 & 0.000 & 0.000 & 0.017 & 0.000 \\
\hline North Dakota & 0.000 & 0.000 & 0.000 & 0.000 & 0.000 & 0.000 & 0.000 & 0.000 \\
\hline Ohio & 0.000 & 0.000 & 0.000 & 0.000 & 0.000 & 0.000 & 0.000 & 0.000 \\
\hline Oklahoma & 0.000 & 0.000 & 0.436 & 0.000 & 0.000 & 0.000 & 0.000 & 0.000 \\
\hline Oregon & 0.000 & 0.000 & 0.000 & 0.000 & 0.000 & 0.000 & 0.086 & 0.000 \\
\hline Pennsylvania & 0.000 & 0.004 & 0.000 & 0.000 & 0.000 & 0.000 & 0.000 & 0.000 \\
\hline Rhode Island & 0.000 & 0.000 & 0.000 & 0.000 & 0.000 & 0.000 & 0.000 & 0.000 \\
\hline South Dakota & 0.000 & 0.000 & 0.000 & 0.000 & 0.000 & 0.000 & 0.000 & 0.000 \\
\hline Tennessee & 0.000 & 0.000 & 0.000 & 0.159 & 0.000 & 0.000 & 0.000 & 0.000 \\
\hline Texas & 0.404 & 0.000 & 0.070 & 0.004 & 0.160 & 0.341 & 0.106 & 0.099 \\
\hline Vermont & 0.000 & 0.000 & 0.000 & 0.000 & 0.000 & 0.000 & 0.000 & 0.000 \\
\hline Virginia & 0.000 & 0.000 & 0.000 & 0.000 & 0.000 & 0.585 & 0.219 & 0.000 \\
\hline Washington & 0.000 & 0.000 & 0.000 & 0.000 & 0.036 & 0.000 & 0.000 & 0.000 \\
\hline West Virginia & 0.000 & 0.035 & 0.000 & 0.000 & 0.000 & 0.000 & 0.021 & 0.026 \\
\hline Wisconsin & 0.000 & 0.000 & 0.000 & 0.000 & 0.000 & 0.000 & 0.000 & 0.000 \\
\hline Wyoming & 0.000 & 0.000 & 0.000 & 0.000 & 0.000 & 0.000 & 0.000 & 0.000 \\
\hline
\end{tabular}


Table A7 Weights used in construction of synthetic Arizona for occupation income score analysis in Table 6

\begin{tabular}{|c|c|c|c|c|}
\hline \multirow[t]{2}{*}{ Donor states } & \multicolumn{2}{|c|}{ Occupation income score } & \multicolumn{2}{|c|}{ Employment rate } \\
\hline & Native male & Native female & Native male & Native female \\
\hline Alaska & 0.000 & 0.000 & 0.000 & 0.000 \\
\hline Arkansas & 0.000 & 0.000 & 0.000 & 0.000 \\
\hline California & 0.000 & 0.099 & 0.338 & 0.000 \\
\hline Colorado & 0.199 & 0.211 & 0.000 & 0.621 \\
\hline Connecticut & 0.000 & 0.000 & 0.000 & 0.000 \\
\hline Delaware & 0.000 & 0.175 & 0.027 & 0.000 \\
\hline District of Columbia & 0.000 & 0.009 & 0.000 & 0.000 \\
\hline Florida & 0.000 & 0.402 & 0.000 & 0.000 \\
\hline Hawaii & 0.000 & 0.000 & 0.000 & 0.000 \\
\hline Idaho & 0.000 & 0.000 & 0.000 & 0.000 \\
\hline Illinois & 0.000 & 0.000 & 0.000 & 0.000 \\
\hline Indiana & 0.000 & 0.000 & 0.000 & 0.000 \\
\hline lowa & 0.000 & 0.000 & 0.000 & 0.000 \\
\hline Kansas & 0.000 & 0.000 & 0.000 & 0.000 \\
\hline Kentucky & 0.000 & 0.000 & 0.000 & 0.000 \\
\hline Louisiana & 0.219 & 0.000 & 0.000 & 0.000 \\
\hline Maine & 0.000 & 0.000 & 0.000 & 0.000 \\
\hline Maryland & 0.184 & 0.024 & 0.007 & 0.000 \\
\hline Massachusetts & 0.000 & 0.000 & 0.000 & 0.000 \\
\hline Michigan & 0.000 & 0.000 & 0.000 & 0.000 \\
\hline Minnesota & 0.000 & 0.000 & 0.000 & 0.000 \\
\hline Missouri & 0.000 & 0.000 & 0.000 & 0.000 \\
\hline Montana & 0.000 & 0.000 & 0.198 & 0.000 \\
\hline Nebraska & 0.000 & 0.000 & 0.000 & 0.000 \\
\hline Nevada & 0.146 & 0.000 & 0.087 & 0.052 \\
\hline New Hampshire & 0.218 & 0.000 & 0.000 & 0.000 \\
\hline New Jersey & 0.000 & 0.000 & 0.000 & 0.000 \\
\hline New Mexico & 0.020 & 0.000 & 0.000 & 0.000 \\
\hline New York & 0.000 & 0.000 & 0.000 & 0.000 \\
\hline North Dakota & 0.000 & 0.000 & 0.000 & 0.000 \\
\hline Ohio & 0.000 & 0.000 & 0.000 & 0.000 \\
\hline Oklahoma & 0.000 & 0.000 & 0.000 & 0.000 \\
\hline Oregon & 0.000 & 0.000 & 0.000 & 0.000 \\
\hline Pennsylvania & 0.000 & 0.000 & 0.000 & 0.000 \\
\hline Rhode Island & 0.000 & 0.000 & 0.000 & 0.000 \\
\hline South Dakota & 0.000 & 0.000 & 0.000 & 0.000 \\
\hline Tennessee & 0.000 & 0.000 & 0.000 & 0.000 \\
\hline Texas & 0.000 & 0.081 & 0.110 & 0.000 \\
\hline Vermont & 0.000 & 0.000 & 0.000 & 0.000 \\
\hline Virginia & 0.014 & 0.000 & 0.000 & 0.000 \\
\hline Washington & 0.000 & 0.000 & 0.044 & 0.030 \\
\hline West Virginia & 0.000 & 0.000 & 0.188 & 0.297 \\
\hline Wisconsin & 0.000 & 0.000 & 0.000 & 0.000 \\
\hline Wyoming & 0.000 & 0.000 & 0.000 & 0.000 \\
\hline
\end{tabular}




\section{(Endnotes)}

1 Cortes and Tessada (2011) found that the time men spent doing household works is between one-third and one-half the amount women making similar wages spent in the United States.

2 It should be noted that this decline was driven not only by out-migration of low-skilled immigrants in the state but also by those who would have immigrated to Arizona in the absence of LAWA.

3 I use STATA's default option for constructing matrix $V$. The default option uses a regression-based method as described in Kaul et al. (2015) in which matching variables that are strong predictors of the dependent variable are given more weight.

4 The weights for all analyses are reported in Tables A1-A7.

5 The Census Bureau collects information from all immigrants regardless of their legal status. As such, foreign-born individuals in the sample include both those who are legally in the US and undocumented immigrants.

6 I exclude Arizona from the donor pool when constructing the synthetic control for other states remaining in the donor pool. As noted by Bohn et al. (2014) and Peri and Yasenov (2018), this specification choice would avoid contaminating the control group if there is any effect of LAWA in Arizona.

7 Based on a suggestion by Abadie et al. (2010) to exclude placebo runs with poor fit prior to treatment period, I exclude California from the permutation test because synthetic California does not closely mimic actual California prior to 2007 in this analysis. Note that California is still used as a potential control state in the donor pool to create synthetic control.

8 A recent work by Hoekstra and Orozco-Aleman (2017) found that S.B. 1070 reduced the flow of undocumented workers to Arizona for a few months after it passed. However, this effect was temporary (mainly from April 2010 to July 2010). After the federal judge blocked the key parts of the bill in July 2010, the influx of undocumented workers rebounded back. Based on the findings by Amuedo-Dorantes and Lozano (2015), it is likely that this reduction in the flow of undocumented immigrants did not substantially affect the population of non-citizen Hispanics in Arizona.

9 This result is comparable to that of Bohn et al. (2015) who found that LAWA has a marginally significant effect in lowering the employment rate of white non-Hispanic US-born men, but it has no statistically significant effect on their labor force participation. This slight difference may arise because Bohn et al. (2015) used different data source in their analysis (CPS). Because the ACS sample size is much larger relative to current population survey (CPS), I used ACS in the analysis.

10 I defined household works' hours as the time spent on "Housework" (ATUS Code = 0201), "Lawn, garden, and houseplants" (ATUS Code = 0205), and "Caring for and helping household children" (ATUS Code = 0301). Because the Synthetic Control Method requires no missing information on the outcome variable in the period of study, I excluded states with missing time use observations in any year in the period of study in time-use analysis. The states used as donor states in this analysis are reported in Table A2.

11 I defined an individual as working in household service occupation if he/she was employed in any of the following occupations: "Housekeepers, maids, butlers, stewards, and lodging quarters cleaners" (OCC1990 = 405), "Gardeners and groundskeepers" (OCC1990 = 486), or "Childcare workers" (OCC1990 =468). To obtain an accurate price of labor, I used the sample of not self-employed individuals aged 18-64 years who were not enrolled in school. I dropped outlying observations defined as those with an hourly wage less than 1.5 dollars or more than 40 dollars.

12 For all analyses in this section, I used the sample of individuals of 18-64 years old.

13 In this analysis, I used IPUMS occupational income score (OCCSCORE), which provides a constructed income score based on the relative economic standing of occupations. The sample used in the analysis is low-skilled US natives who are neither self-employed nor in school between the ages of 18 and 64 years.

14 It is possible that the increase in the number of native workers in household service occupations simply reflects an improvement in the labor market opportunities among low-skilled US-born individuals due to LAWA. In other words, LAWA lowers the probability of nonemployment among low-skilled natives. To check this, I analyzed whether the employment rate of low-skilled US-born individuals was improved by LAWA (Panel B of Table 6 and Figures A31 and A32). The results of the analysis suggest that this is not the case.

15 Indeed, a recent study by Liou and Halliday (2016) documents a considerable increase in Mexican population in New Mexico after LAWA. 